\title{
CHARACTERIZATION OF BRAZING ALLOYS \\ WITH STAINLESS STEELS
}

David H. Riefenberg

Joe H. Doyle

Richard F. Hillyer

William S. Bennett

Research and Development

PHYSICAL METALLURGY GROUP

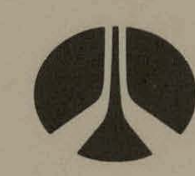

Rockwell International

Atomics International Division

Rocky Flats Plant

P.O. Box 464

Golden, Colorado 80401

U. S. ENERGY RESEARCH AND DEVELOPMENT ADMINISTRATION

Prepared under Dow Chemical Contract

AT (29-1)-1106

Printed under Contract E(29-2)-3533 


\section{DISCLAIMER}

This report was prepared as an account of work sponsored by an agency of the United States Government. Neither the United States Government nor any agency Thereof, nor any of their employees, makes any warranty, express or implied, or assumes any legal liability or responsibility for the accuracy, completeness, or usefulness of any information, apparatus, product, or process disclosed, or represents that its use would not infringe privately owned rights. Reference herein to any specific commercial product, process, or service by trade name, trademark, manufacturer, or otherwise does not necessarily constitute or imply its endorsement, recommendation, or favoring by the United States Government or any agency thereof. The views and opinions of authors expressed herein do not necessarily state or reflect those of the United States Government or any agency thereof. 


\section{DISCLAIMER}

Portions of this document may be illegible in electronic image products. Images are produced from the best available original document. 
-LEGAL NOTICE

This report was prepared as an account of work sponsored by the United States Government. Neither the United States nor the Energy Research and Development Administration, nor any of their employees, nor any of their contractors, subcontractors, or their employees, makes any warranty, expressed or implied, or assumes any legal liability or responsibility for the accuracy, completeness or usefulness of any information, apparatus, product or process disclosed, or represents that its use would not infringe privately owned rights.

Printed in the United States of America

Available from the

National Technical Information Service

U.S. Department of Commerce

Sprıngtield, Virginia 22161

Price: Printed Copy $\$ 4.00$ Microfiche $\$ 2.25$ 


\title{
CHARACTERIZATION OF BRAZING ALLOYS WITH STAINLESS STEELS
}

\author{
David $H$. Riefenberg \\ Joe H. Doyle \\ Rlchurd F. Hillyer \\ William S. Bennett
}

Research and Development

PHYSICAL METALLURGY GROUP

SUBJECT DESCRIPTORS

Brazing

Alloys

Stainless Steel

ROCKWELL INTERNATIONAL

ATOMICS INTERNATIONAL DIVISION ROCKY FLATS PLANT

P.O. BOX 464

GOLDEN, COLORADO 80401

Prepared under Dow Chemical Contract AT (29-1)-1 106

Printed under Contract E(29-2)-3533

for the

Albuquerque Operations Officis

U. S. Energy Research and Development Administration

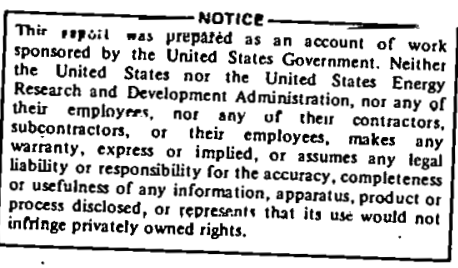

sponsored by the United as an account of work Re United States nor the United States Energ subcomplos warraniy, express or implied, or assumes any leag or usefulness of any informalion, appey, completeness infringe privately owned rights. 


\section{CONTENTS}

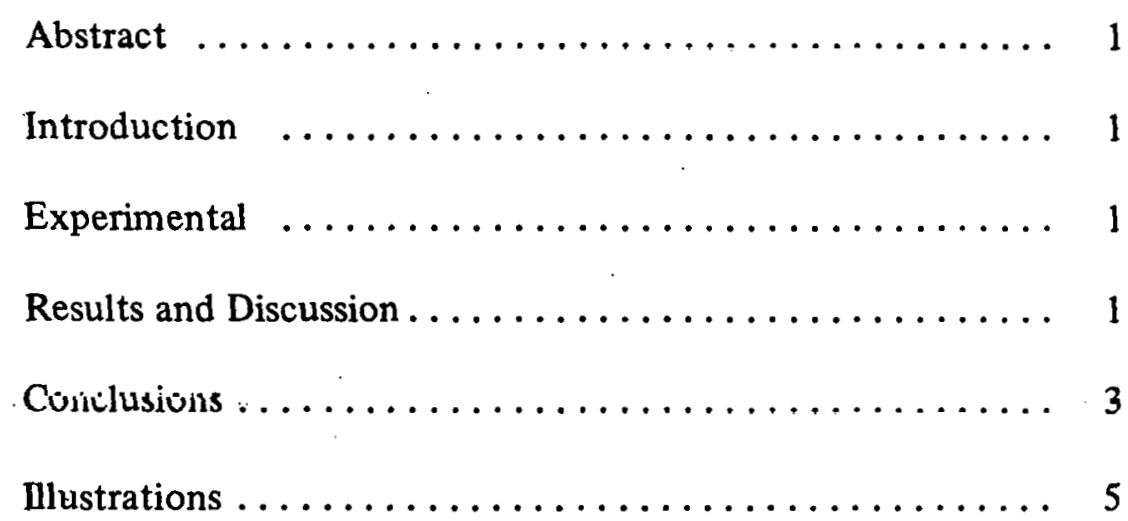

Figures 1 through 26 


\title{
CHARACTERIZATION OF BRAZING ALLOYS WITH STAINLESS STEELS
}

\author{
David H. Riefenberg, Joe H. Doyle, Richard F. Hillyer, and William S. Bennett
}

\begin{abstract}
To simulate braze joints, qualitative $\mathrm{X}$-ray mapping of the elemental interactions between brazing alloys and two common types of stainless steels has been performed via the electron microprobe. In general both steels, Types 304L and $21-6-9$, react with a particular brazing alloy in a similar manner, the exceptions being the goldcopper brazing alloys which show deeper penetration into the 21-6-9 stainless steel.
\end{abstract}

\section{INTRODUCTION}

Increasing use is being made of a high manganese stainless steel (21-6-9) in applications requiring brazed joints. A direct comparison of the braze alloy to stainless steel interface reactions of both 21-6-9 and 304L stainless steels was in order. The chemistry composition limits for both types of stainless steels are given in Table I. A total of thirteen common stainless steel brazing alloys were compared. Most of the alloys were based on the silver-copper eutectic with additions of various

TABLE I. Chemistry Limits for Stainless Steels in Weight Percent.

Stainless Steels

\begin{tabular}{|c|c|c|}
\hline Element & Type-304L & Type-21-6-9 \\
\hline Chromium & 18.0 to 20.0 & 18.0 to 21.0 \\
\hline Nickel & 8.0 to 12.0 & 5.5 to 7.5 \\
\hline Manganese & 2.0 Maximum & 8.0 to 10.0 \\
\hline Silicon & 1.0 Maximum & 1.0 Maximum \\
\hline Sulfur & 0.030 Maximum & 0.030 Maximum \\
\hline Phosphorus & 0.045 Maximum & 0.060 Maximum \\
\hline Carbon & 0.030 Maximum & 0.040 Maximum \\
\hline Nitrogen & & 0.15 to 0.40 \\
\hline
\end{tabular}

elements to enhance wettability. Presented in tabular form in Table II is complete information on the brazing alloys, with the brazing temperatures used in this study. The majority of these alloys are known to perform well with the 300 series stainless steels.

\section{EXPERIMENTAL}

Metallographically prepared stainless steel samples, with the braze metal on the sample surface, were placed in a standard cold-wall vacuum furnace. ${ }^{1}$ Chromel-Alumel thermocouples were inserted into each sample. The furnace was evacuated to $5 \times 10^{-5}$ torr (133 pascals), or lower. The samples were heated to the selected brazing temperature and held for 5 minutes. The samples were then cooled to at least $150^{\circ} \mathrm{C}$, by flowing helium, before removal from the furnace.

Cross sections through the center of the braze metals were prepared metallographically. The cross sections were analyzed with the electron microprobe. A backscattered electron micrograph (BSE) with accompanying X-ray elemental maps of each major alloying element in the stainless steel and braze metal was made for each cross section. All micrographs are 500X magnification and the elemental X-ray micrographs should be indexed to the BSE micrograph in each figure. Such analysis is qualitative in nature and presents a visual profile of the elemental distribution at the stainless steel-braze interface.

\section{RESULTS AND DISCUISSION}

Figures 1 through 6 are typical interfaces for the silver-copper-palladium alloys. Figures 1 and 2

\footnotetext{
${ }^{1}$ W. S. Bennett, R. F. Hillyer, D. L. Keller, and D. H. Riefenberg. "Vacuum Brazing Studies on High Manganese Stainless Steel." Welding Journal 53:510-516. 1974.
} 
TABLE II. Data on Brazing Alloys and Related Temperatures.

\begin{tabular}{|c|c|c|c|c|c|c|c|c|c|c|c|}
\hline \multirow{2}{*}{$\begin{array}{c}\text { Figure } \\
\text { No. } \\
\end{array}$} & \multirow[b]{2}{*}{ Braze Alloy } & \multicolumn{7}{|c|}{$\frac{\text { Composition }}{\text { (weight percent) }}$} & \multirow{2}{*}{$\begin{array}{l}\text { Liquidus } \\
\left({ }^{\circ} \mathrm{C}\right) \\
\end{array}$} & Solidus & Brazing \\
\hline & & Gold & Silver & Copper & Palladium & Tin & Manganese & Nickel & & $\left({ }^{\circ} \mathrm{C}\right)$ & $\left({ }^{\circ} \mathrm{C}\right)$ \\
\hline 1,2 & Palcusil 10 & & 58 & 32 & 10 & & & & 852 & 824 & 900 \\
\hline 3,4 & Palcusil 15. & & 65 & 20 & 15 & & & & 900 & 850 & 900 \\
\hline 5,6 & Palcusil 15 & & 65 & 20 & 15 & & & & 900 & 850 & 1000 \\
\hline 7,8 & 071 & & 7 & 85 & & 8 & & & 985 & 665 & 1000 \\
\hline 9,10 & 580 & & 57 & 33 & & 7 & 3 & & 730 & 605 & 800 \\
\hline 11,12 & Cusiltin & & 60 & 30 & & 10 & & & 720 & 600 & 850 \\
\hline 13,14 & 630 & & 63 & 28 & & 6 & & 3 & 800 & 690 & 850 \\
\hline 15,16 & 655 & & 65 & 28 & & & 5 & 2 & 850 & 750 & 900 \\
\hline 17,18 & Nicusil & & 71.5 & 28 & & & & 0.5 & 795 & 780 & 900 \\
\hline 19,20 & 852 & & 85 & & & & 15 & & 970 & 960 & 1050 \\
\hline 21,22 & Silcoro 60 & 60 & 20 & 20 & & & & & 845 & $83 n$ & 1000 \\
\hline 23,24 & Nicoro 80 & 81.5 & & 16 & & & & 2.5 & 925 & 910 & 1000 \\
\hline 25,26 & Nioro & 82 & & & & & & 18 & 950 & 950 & 1000 \\
\hline
\end{tabular}

(Palcusil 10) with 10 weight percent palladium at $900{ }^{\circ} \mathrm{C}$ show little penetration of iron into the braze alloy at the interface. Also showing little, if any, penetration of iron into the braze alloy is the 15 weight percent palladium at $900{ }^{\circ} \mathrm{C}$, Figures 3 and 4 (Palcusil 15). A more severe interface reaction takes place with the 15 weight percent palladium when the brazing temperature is raised to $1000^{\circ} \mathrm{C}$, as viewed in Figures 5 and $6 .^{2}$

A silver-copper-tin noneutectic braze alloy is shown in Figures 7 and $8(071)$. This particular alloy is low in silver content, around 7 weight percent. Copper penetration into the 21-6-9 base metal is much greater than into the $304 \mathrm{~L}$ stainless steel.

Figures 9 and $10(580)$ are of a silver-copper-tinmanganese braze alloy. Manganese content in this alloy is a low 3 weight percent. No penetration of

\footnotetext{
${ }^{2}$ Figures follow in sequence at end of text.
}

the braze alloy constituents into the two base metals was apparent.

In Figures 11 and 12 (Cusiltin), a silver-ronper-tin braze alloy with 10 weight percent tin and a noninterface layer forms. Slight copper penetration into the 21-6-9 base metal is noticeable. No copper penetration intrudes into the $304 \mathrm{~L}$ base metal.

A last example of a braze alloy containing tin is presented in Figures 13 and 14 (630). This is a silver-copper-tin-nickel alloy. Nickel content is 3 weight percent. The interface reaction on each steel is identical. Note the concentration of nickel at the base metal interfaces, with little niokol present in the bulk of the braze metal.

Figures 15 and $16(655)$ show a silver-copper brazing alloy containing nickel and manganese. An increased concentration of nickel, copper, and manganese appear at the interface of both $21 \cdot 6-9$ 
and $304 \mathrm{~L}$ stainless steels. The interface elemental reactions are identical.

A silver-copper eutectic brazing alloy containing 0.5 weight percent nickel is shown in Figures 17 and 18 (Nicusil). The reactions are identical for both stainless steel base metals. A continuous layer of copper-nickel has formed at the interface. All of the nickel present in the braze metal alloy is concentrated at the interface area.

A silver-manganese alloy is shown in Figures 19 and 20 (852). No dissolution of one material into another can be seen. Little interface reaction appears in either of the base metals or the braze alloy.

The following figures from 21 through 26 are representative of brazing alloys containing gold. Figures 21 and 22 (Silcoro 60) consist of a goldsilver-copper alloy. Penetration of the braze alloy into both stainless steel base metals is apparent. Much greater penetration has occurred in 21-6-9 than in 304L. Notice the displacement of loosened grains from the stainless steel into the brazing alloy. Also note the lack of manganese in these grains and a depletion of manganese in the area where the braze metal has penetrated.

Figures 23 and 24 (Nicoro 80 ) are typical of a gold-copper-nickel brazing alloy. The reaction between the two stainless steel base metals and the brazing alloy is much different. On $304 \mathrm{~L}$, moderate iron and nickel penetration occurs into the braze material with slight copper erosion into the stainless-steel grain boundaries. On the 21-6-9 base metal, both copper and gold have penetrated to a great depth. Stainless-steel grains have dispersed into the brazing alloy. Manganese has moved entirely out of the affected region.

A gold-nickel brazing alloy is shown in Figures 25 and 26 (Nioro). Iron has penetrated into the braze metal in both cases, with the deepest penetration occurring in 21-6-9. Gold and nickel distribution appears uniform for both basc materials.

\section{CONCLUSIONS}

1. Silver-copper eutectic alloys with 10 weight percent or 15 weight percent palladium perform satisfactorily on both $304 \mathrm{~L}$ and 21-6-9 stainless steels at brazing temperatures of 900 and $1000^{\circ} \mathrm{C}$.

2. Eutectic type silver-copper-tin brazing alloys react favorably with both base metals near $800^{\circ} \mathrm{C}$ brazing temperatures. Manganese as an additive to silver-copper-tin alloys helps the wetting process and also gives good results with both stainless steels. If nickel is substituted for manganese in the silver-coppertin brazing alloy, a nickel-rich interface forms on both 304L and 21-6-9.

3. Noneutectic silver-copper-tin alloys, Type 071 at $1000{ }^{\circ} \mathrm{C}$, show severe copper grain-boundary penetration into both $304 \mathrm{~L}$ and 21-6-9 stainless steels. This braze should be used with caution, especially with 21-6-9.

4. On brazing alloys containing no tin, such as a silver-copper eutectic containing both nickel and manganese as alloys, results are identical on both base stainless steels. Nickel, copper, and manganese are concentrated at the interface. In the case of a silver-copper-nickel brazing alloy, copper and nickel are high at the interface area, with all of the nickel from the braze metal concentrated in this area.

5. The silver-manganese braze alloy at high temperatures, $1050^{\circ} \mathrm{C}$, shows little interaction with either $304 \mathrm{~L}$ or 21-6-9 stainless steels.

6. Gold-copper based brazing alloys show severe erosion on 21-6-9 stainless steel base metal. Moderate erosion occurs also in 304 L stainless steel. These alloys would be unsatisfactory on 21-6-9 stainless steel but may have some limited applications with $304 \mathrm{~L}$ stainless steel. 
RFP-2233

I L L U S T R A T I O N S

Figures 1 through 26 

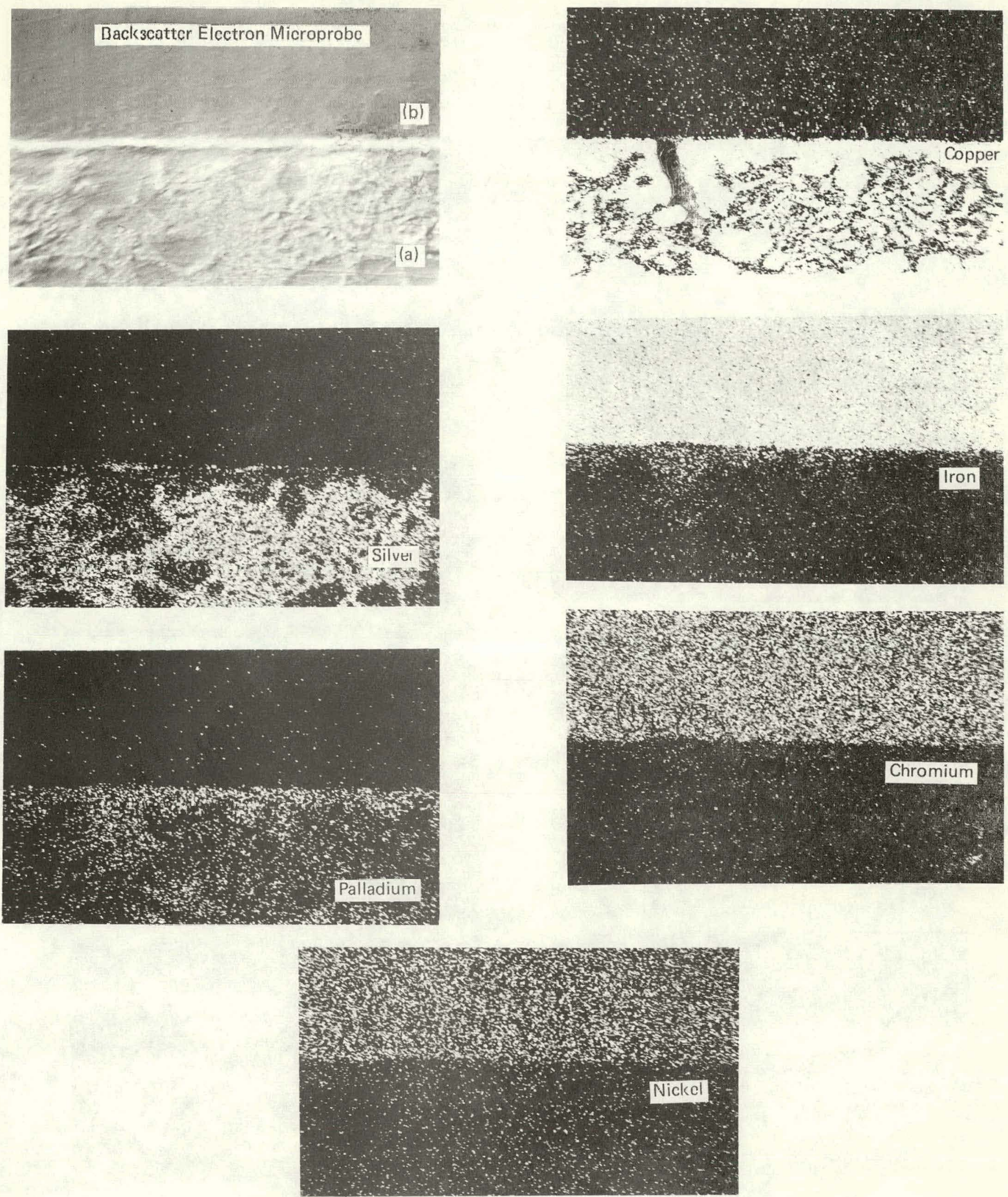

FIGURE 1. Palcusil 10 (a) (with weight percents: 58 silver, 32 copper, and 10 palladium) on Type-304L Stainless Steel (b) at $900{ }^{\circ} \mathrm{C}$. Magnification 88 percent of $500 \mathrm{X}$. 

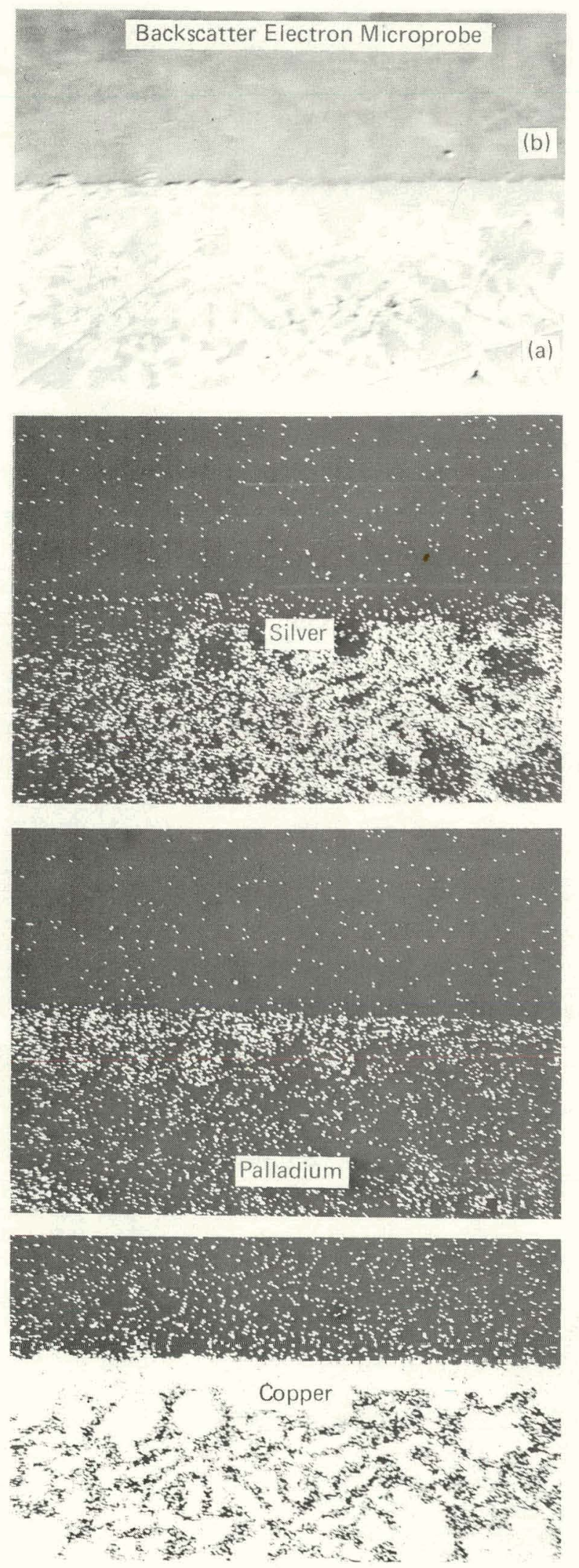
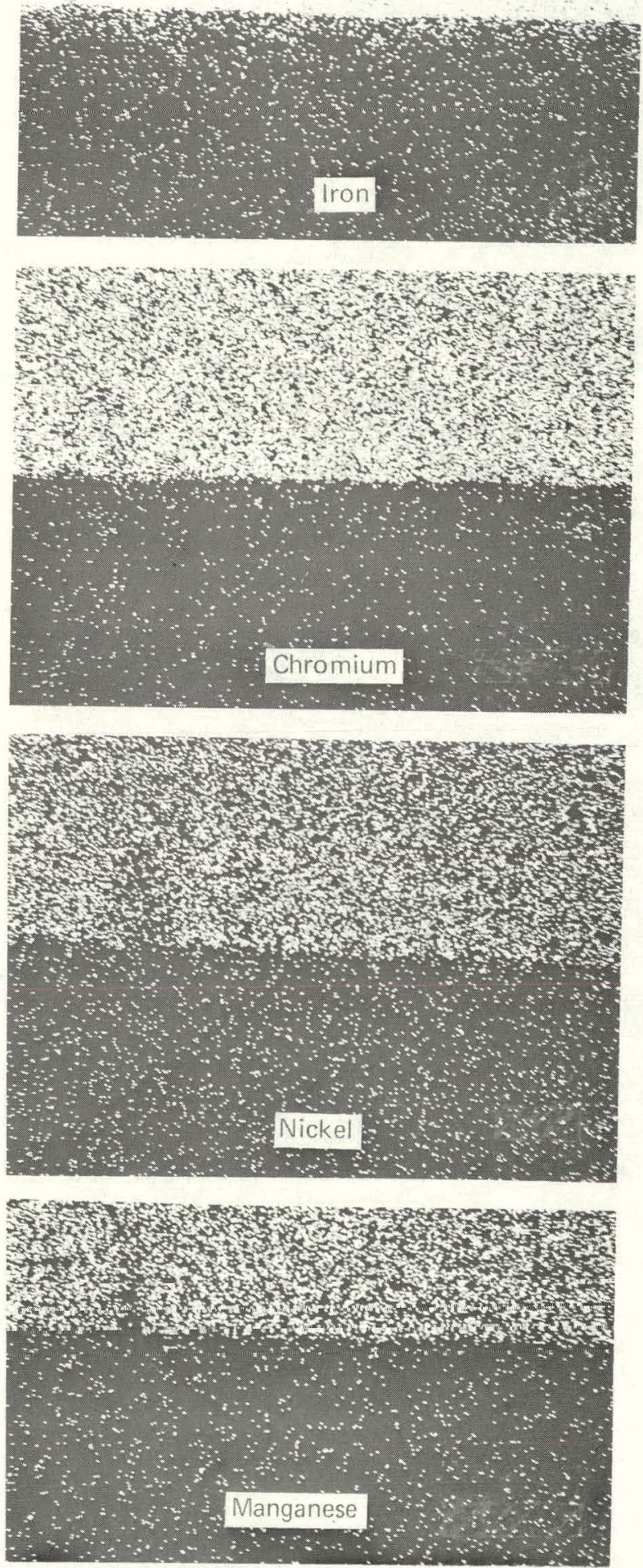

FIGURE 2. Palcusil 10 (a) (with weight percents: 58 silver, 32 copper, and 10 palladium) on Type 21-6-9 Stainless Steel (b) at $900{ }^{\circ} \mathrm{C}$. Magnification 88 percent of $500 \mathrm{X}$. 

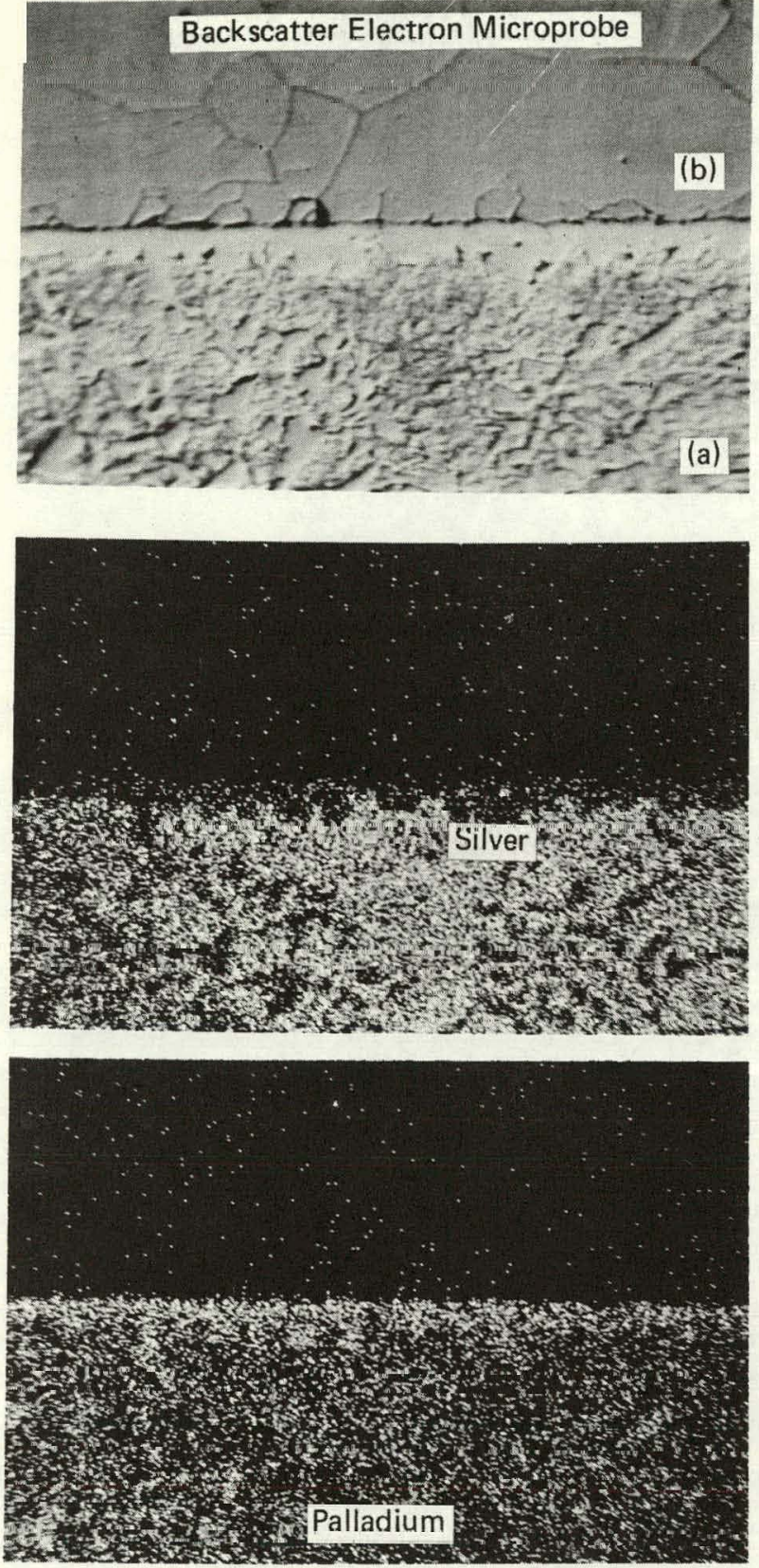
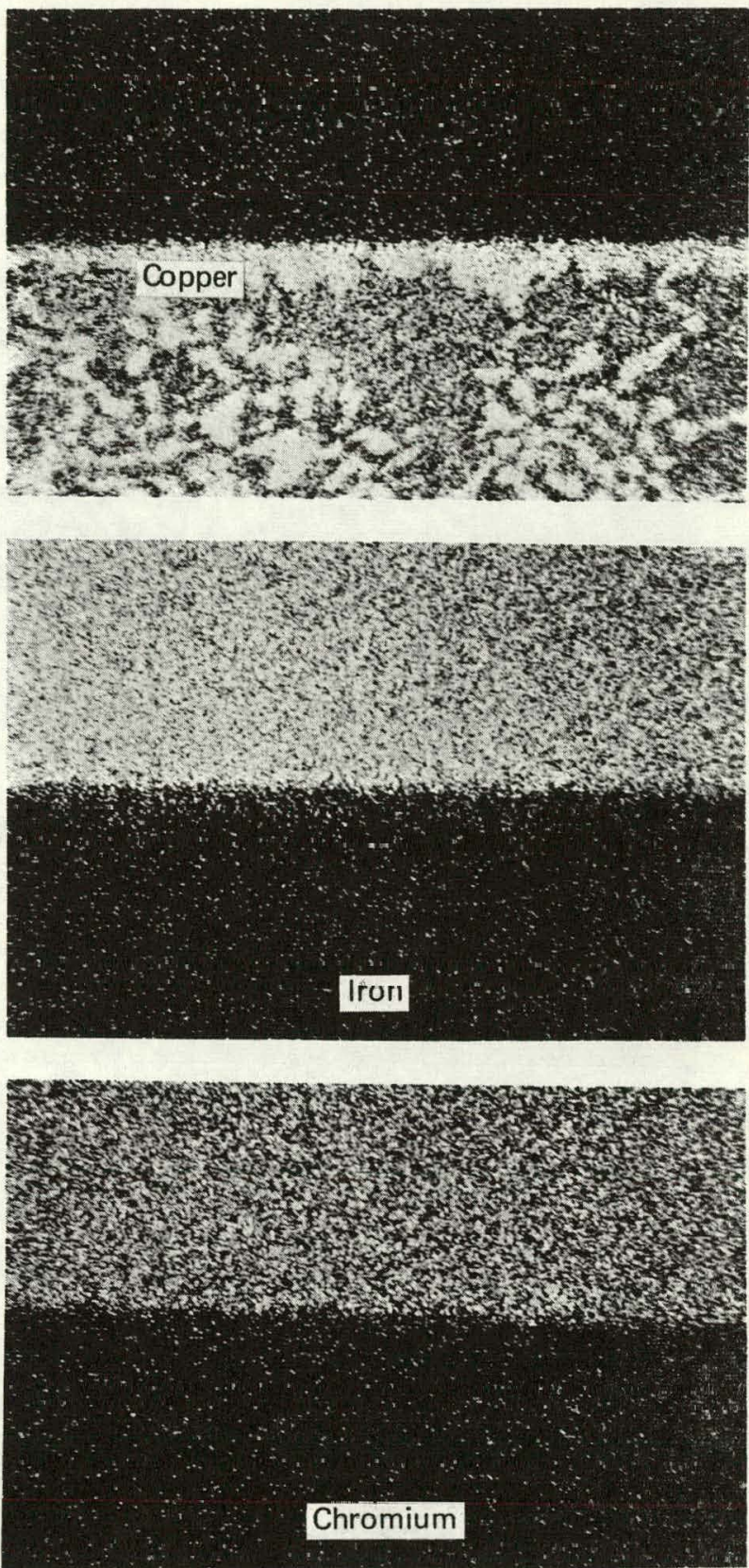

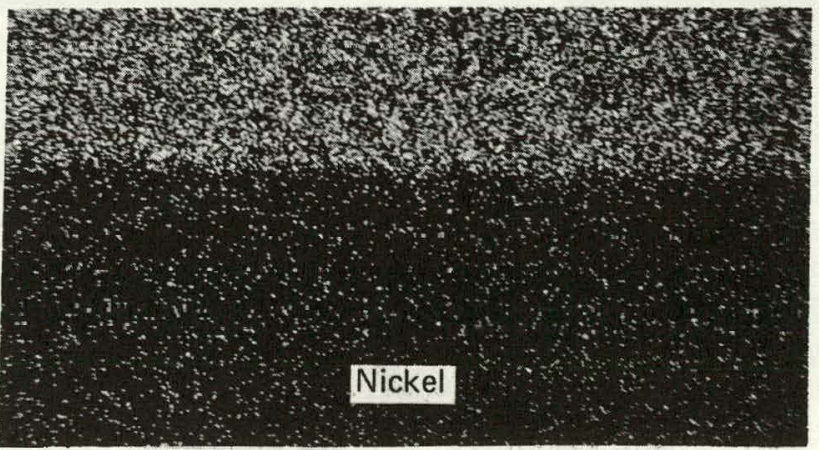

FIGURE 3. Palcusil 15 (a) (with weight percents: 65 silver, 20 copper, and 15 palladium) on Type-304L Stainless Steel (b) at $900{ }^{\circ} \mathrm{C}$. Magnification 88 percent of $500 \mathrm{X}$. 

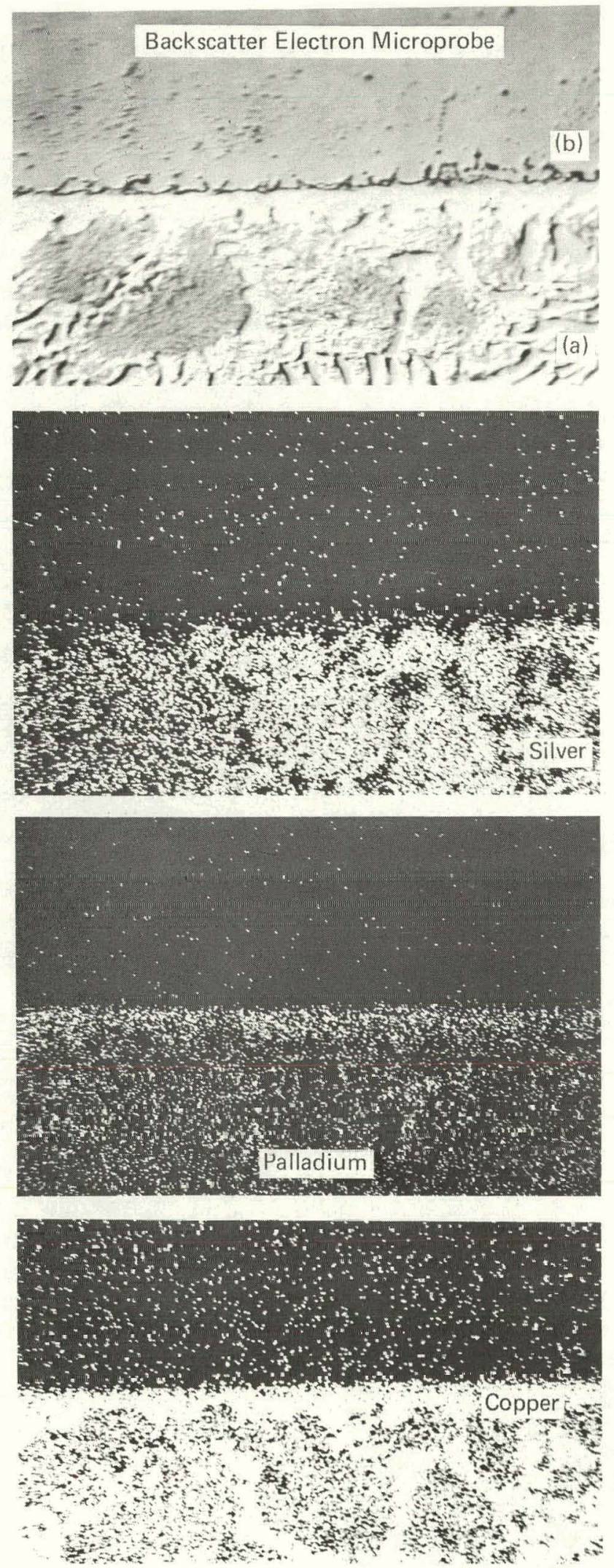
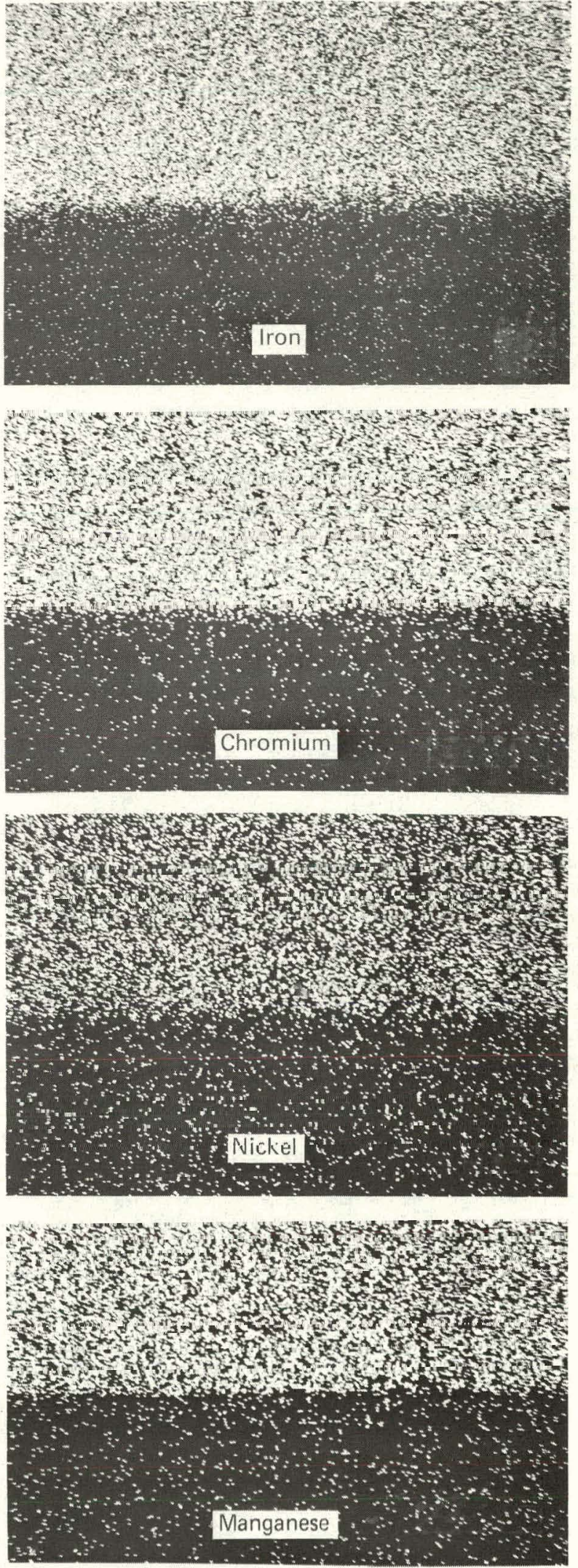

FIGURE 4. Palcusil 15 (a) (with weight percents: 65 silver, 20 copper, and 15 palladium) on Type 21-6-9 Stainless Steel (b) at $900{ }^{\circ} \mathrm{C}$. Magnification 88 percent of $500 \mathrm{X}$. 

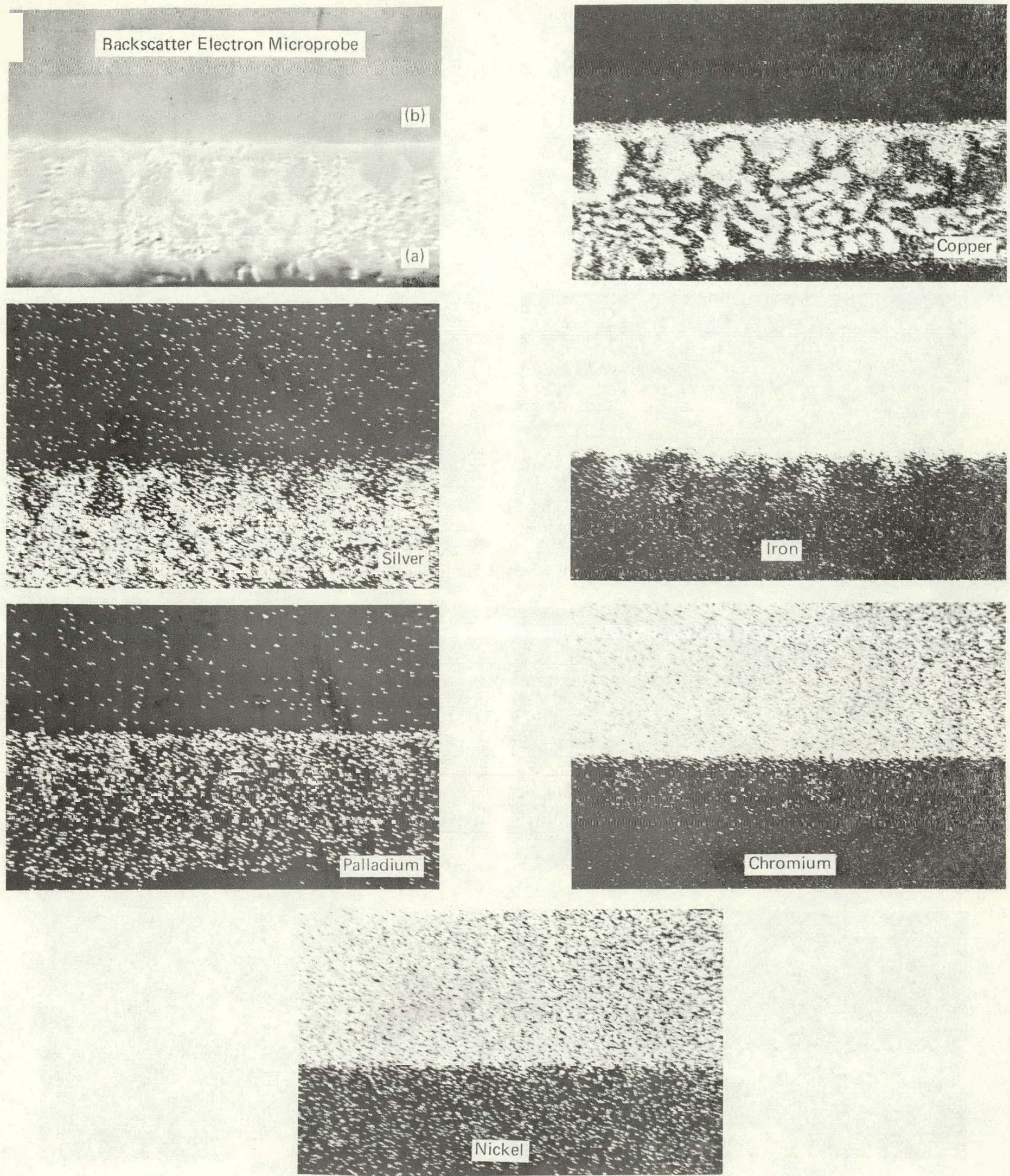

FIGURE 5. Palcusil 15 (a) (with weight percents: 65 silver, 20 copper, and 15 palladium) on Type-304L Stainless Steel (b) at $1000^{\circ} \mathrm{C}$. Magnification 88 percent of 500X. 

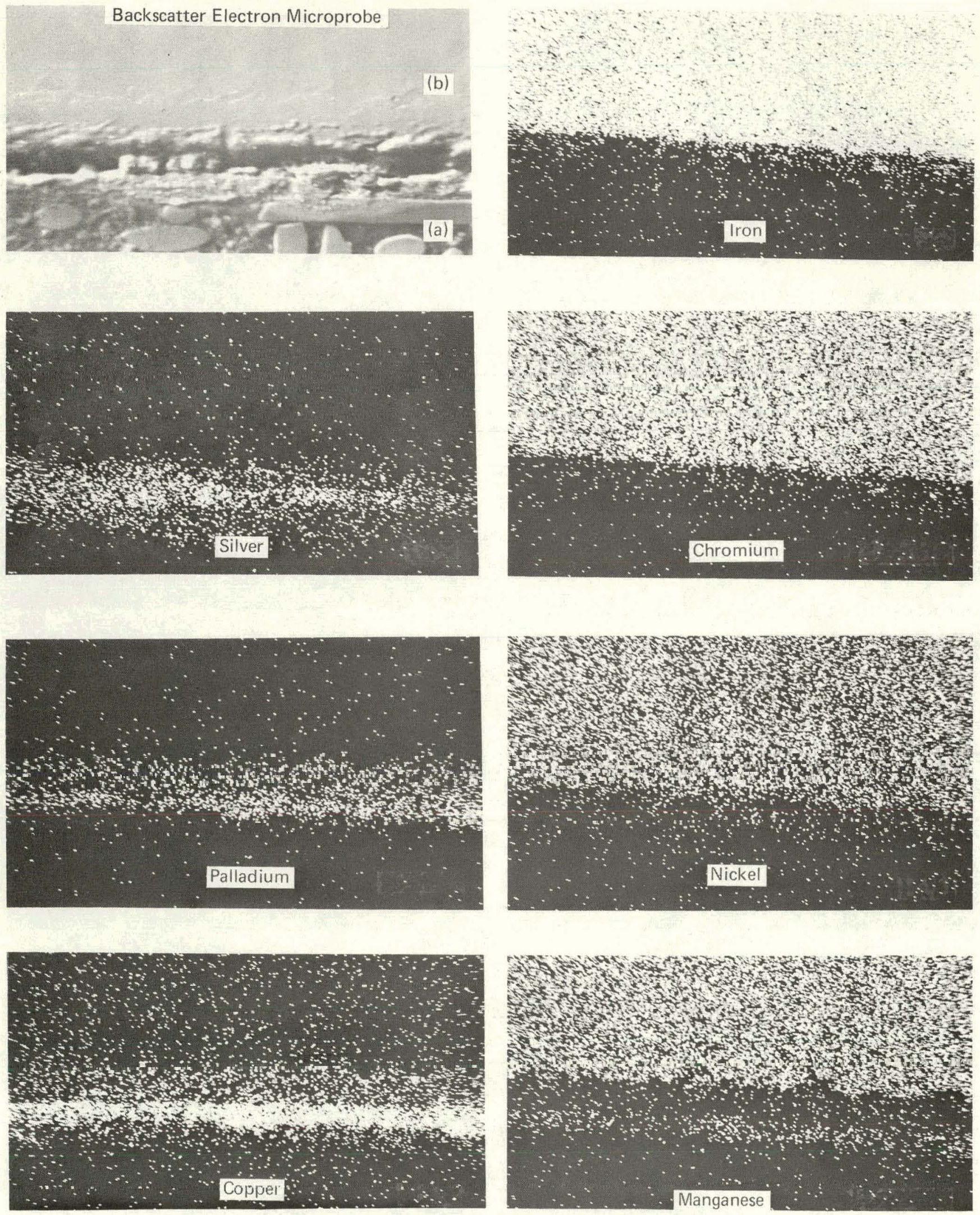

FIGURE 6. Palcusil 15 (a) (with weight percents: 65 silver, 20 copper, and 15 palladium) on Type 21-6-9 Stainless Steel (b) at $1000^{\circ} \mathrm{C}$. Magnification 88 percent of $500 \mathrm{X}$. 

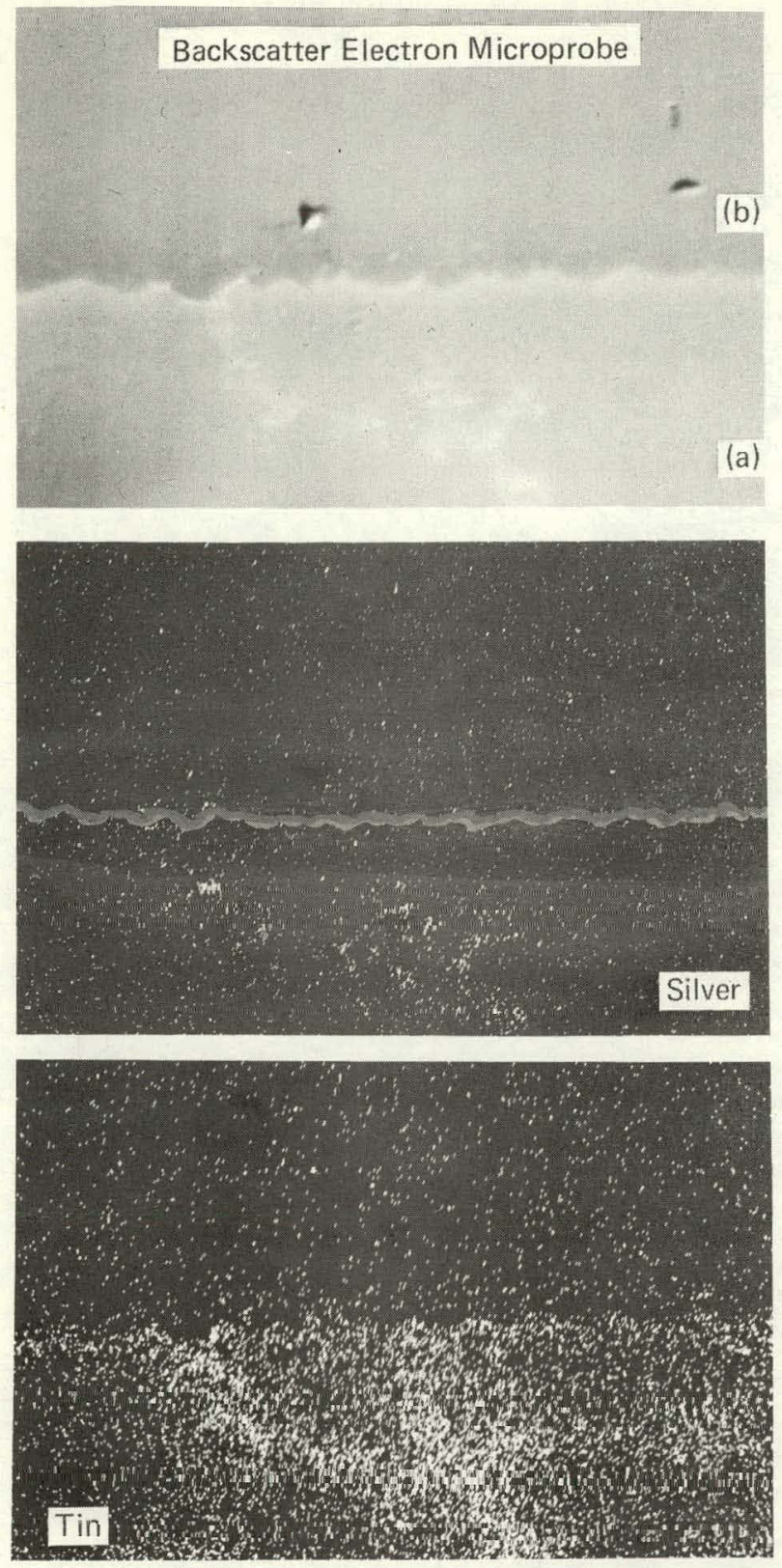
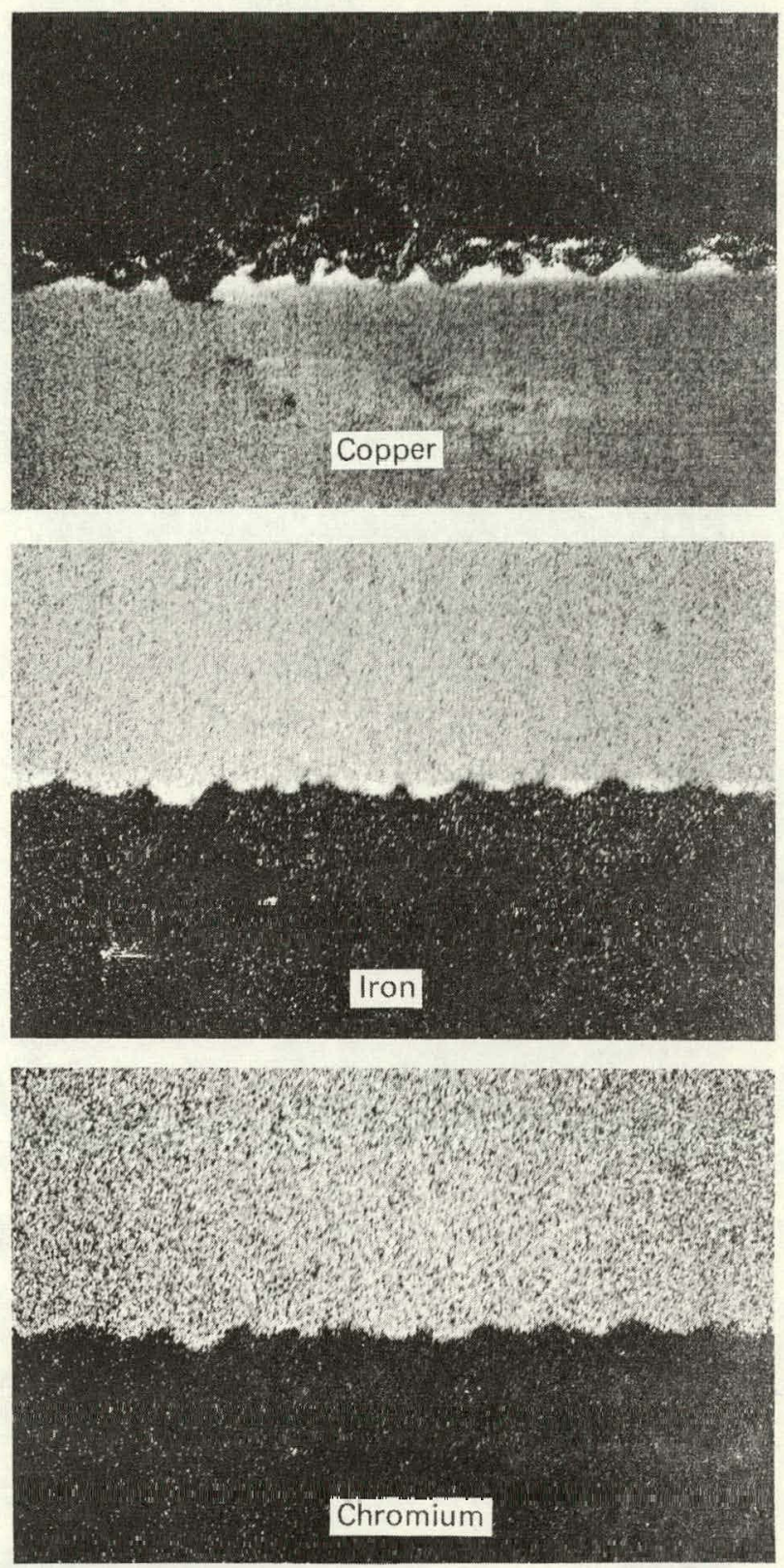

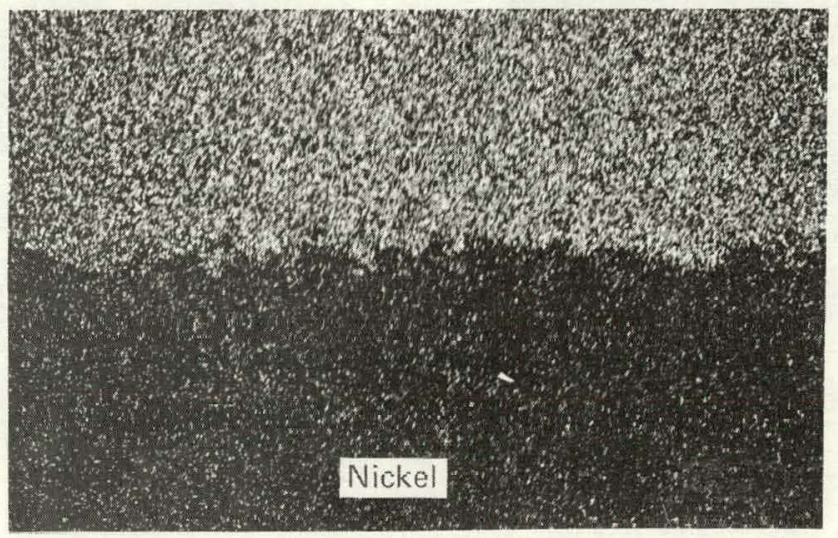

FIGURE 7. No. 071 (a) (with weight percents: 7 silver, 85 copper, and 8 tin) on Type-304L Stainless Steel (b) at $1000{ }^{\circ} \mathrm{C}$. Magnification 88 percent of $500 \mathrm{X}$. 

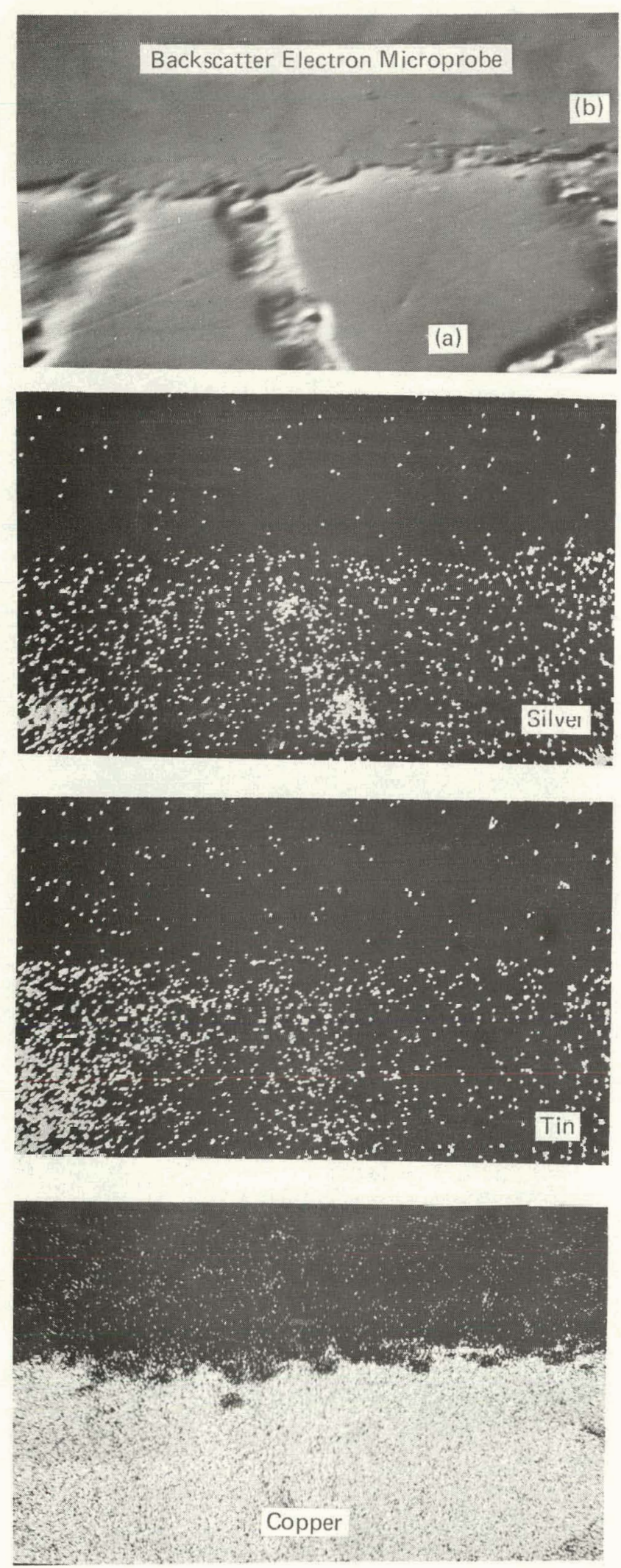
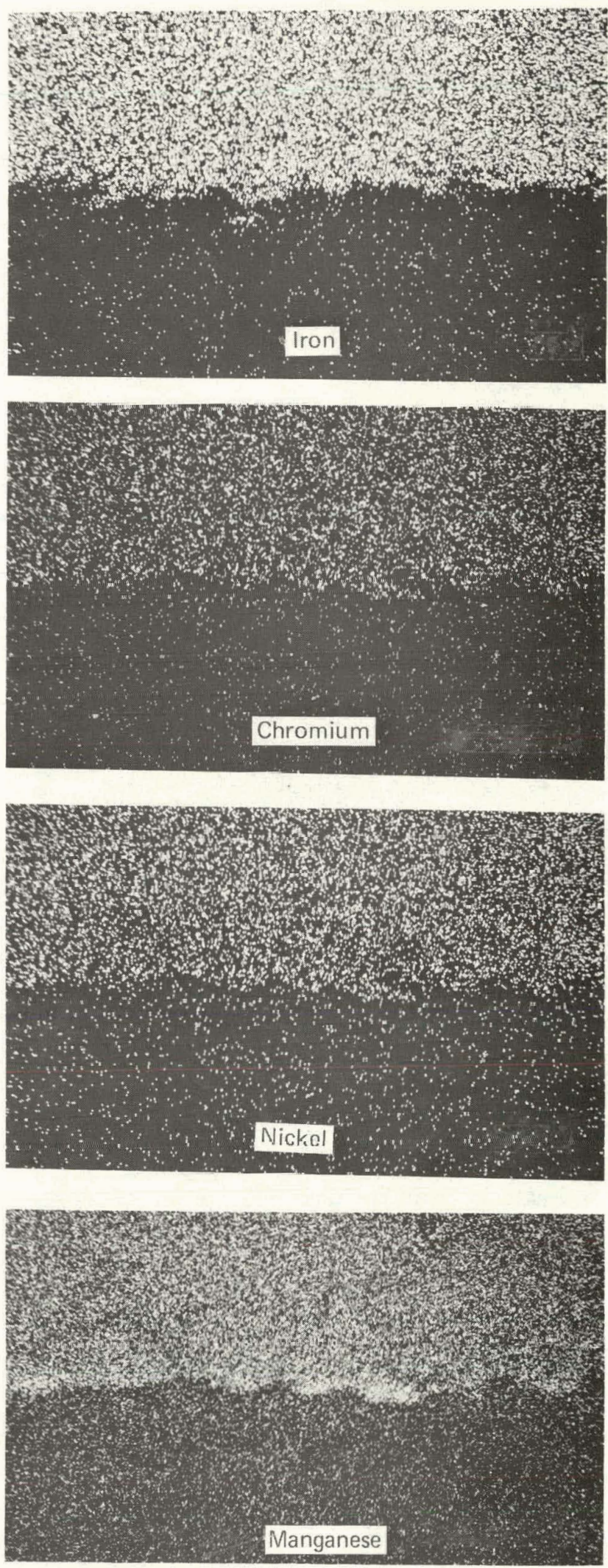

FIGURE 8. No. 071 (a) (weight percents: 7 silver, 85 copper, and 8 tin) on Type 21-6-9 Stainless Steel (b) at $1000{ }^{\circ} \mathrm{C}$. Magnification 88 percent of 500X. 

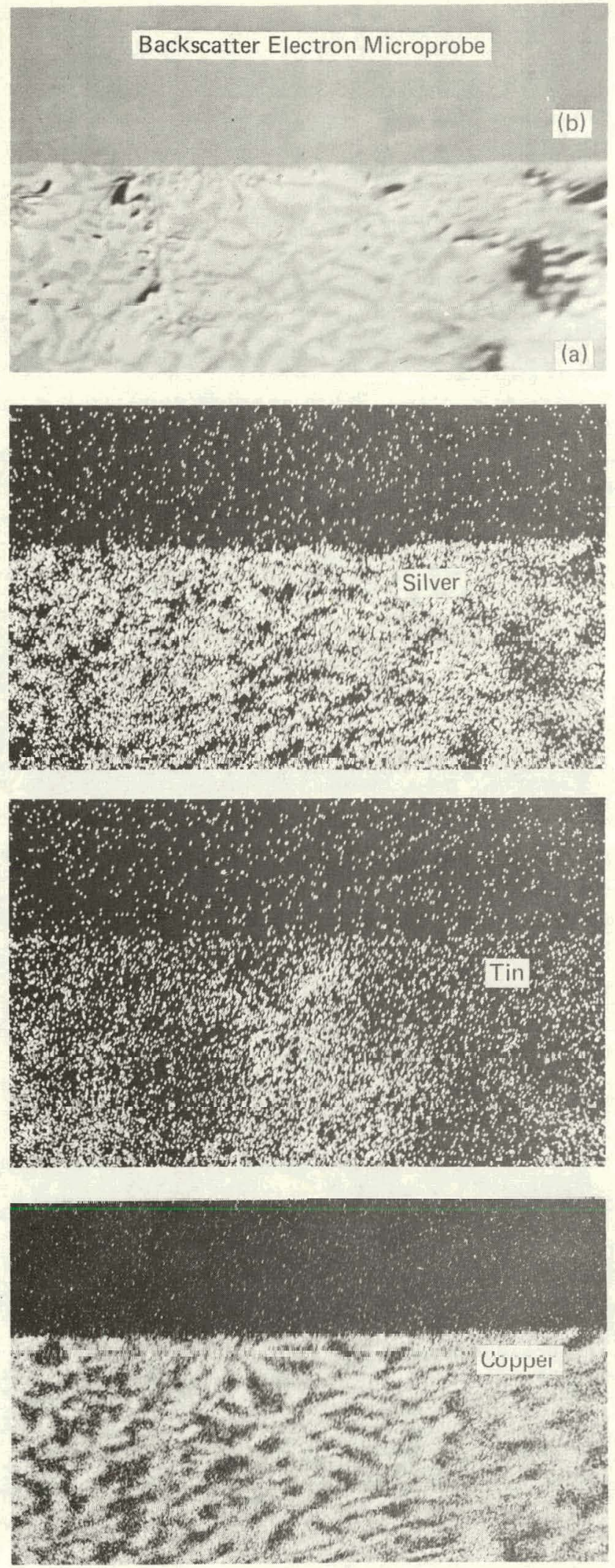
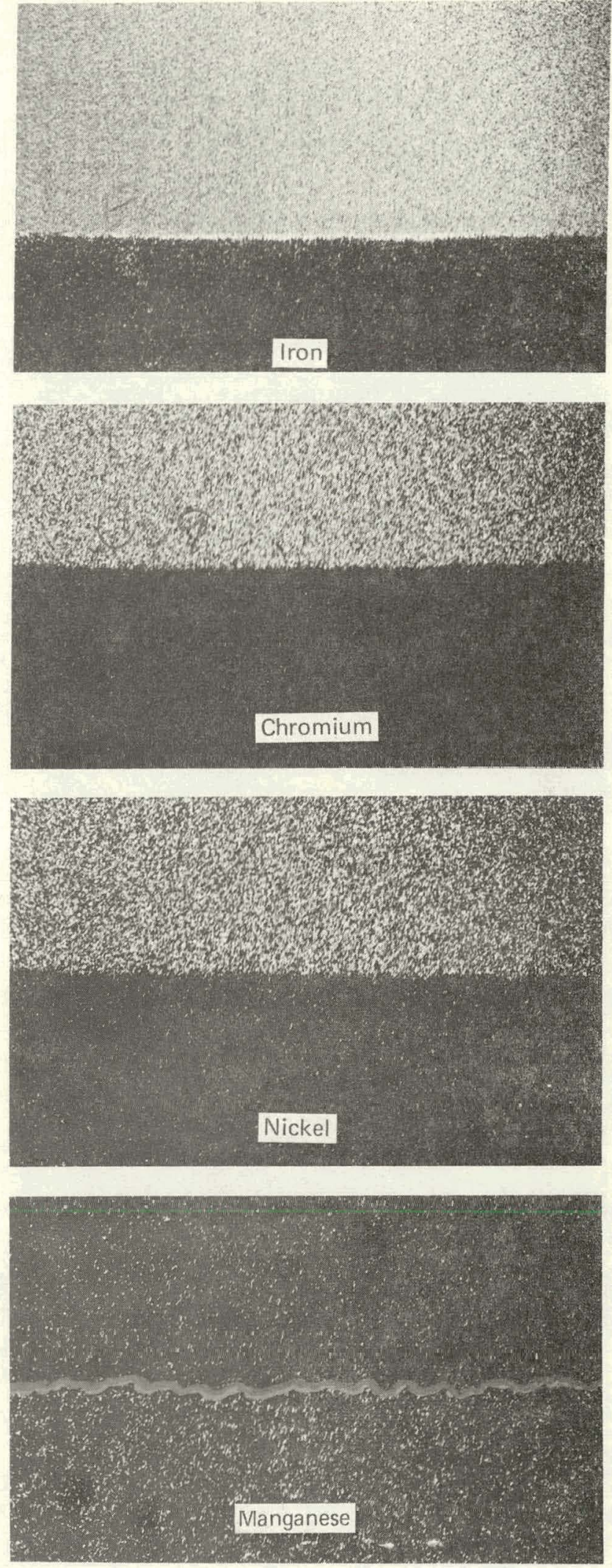

FIGURE 9. No. 580 (a) (weight percents: 57 silver, 33 copper, 7 tin, and 3 manganese) on Type-304L Stainless Steel (b) at $800{ }^{\circ} \mathrm{C}$. Magnification 88 percent of $500 \mathrm{X}$. 

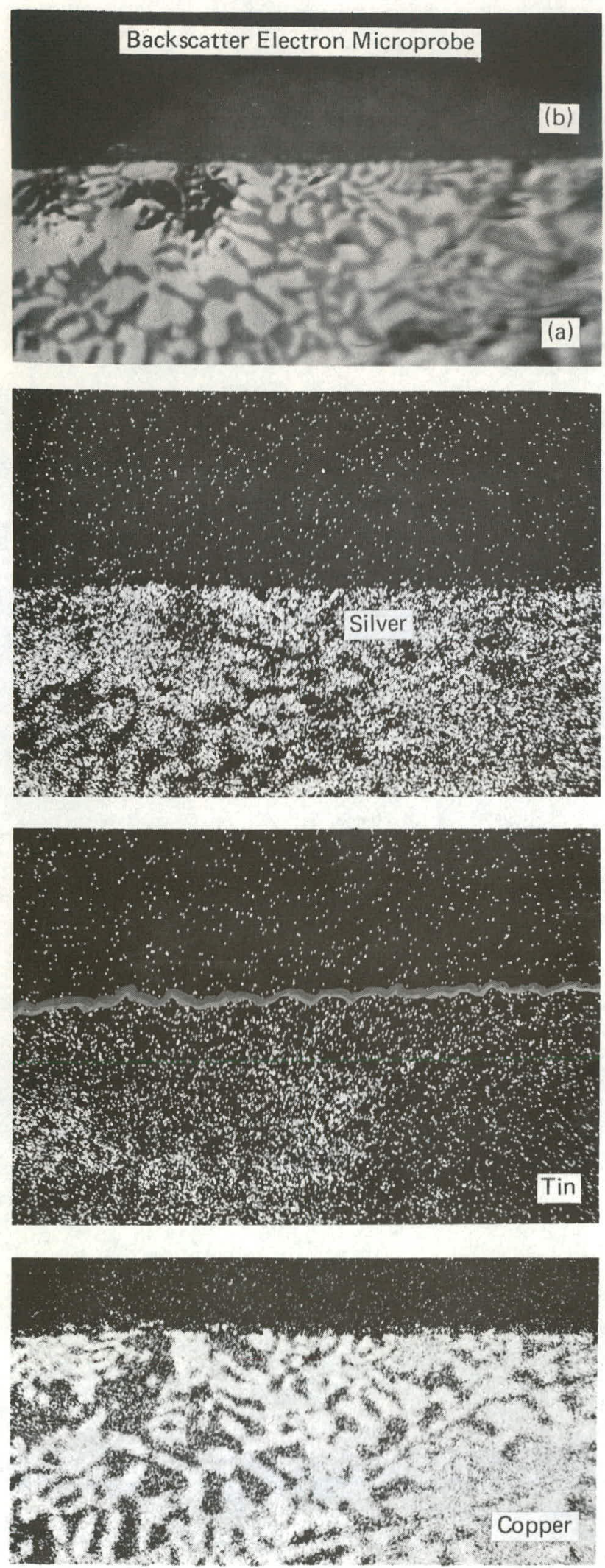
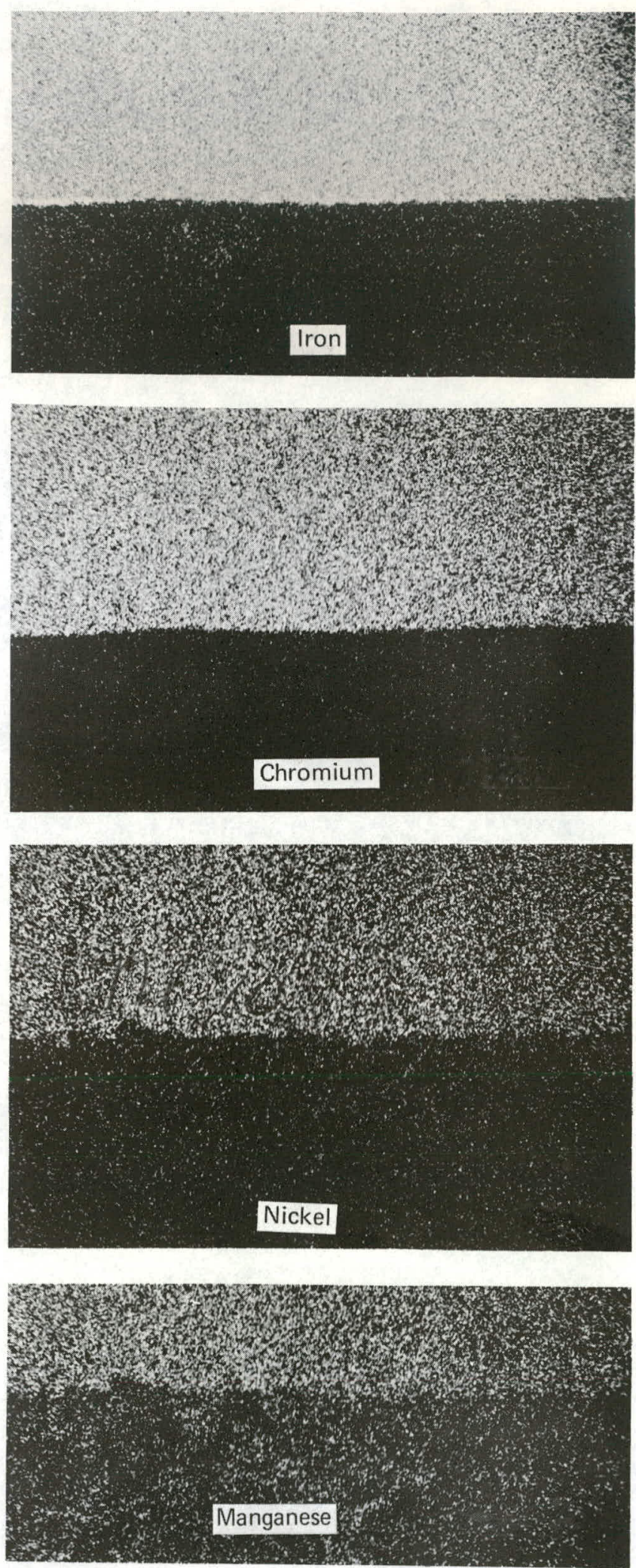

FIGURE 10. No. 580 (a) (weight percents: 57 silver, 33 copper, 7 tin, and 3 manganese) 

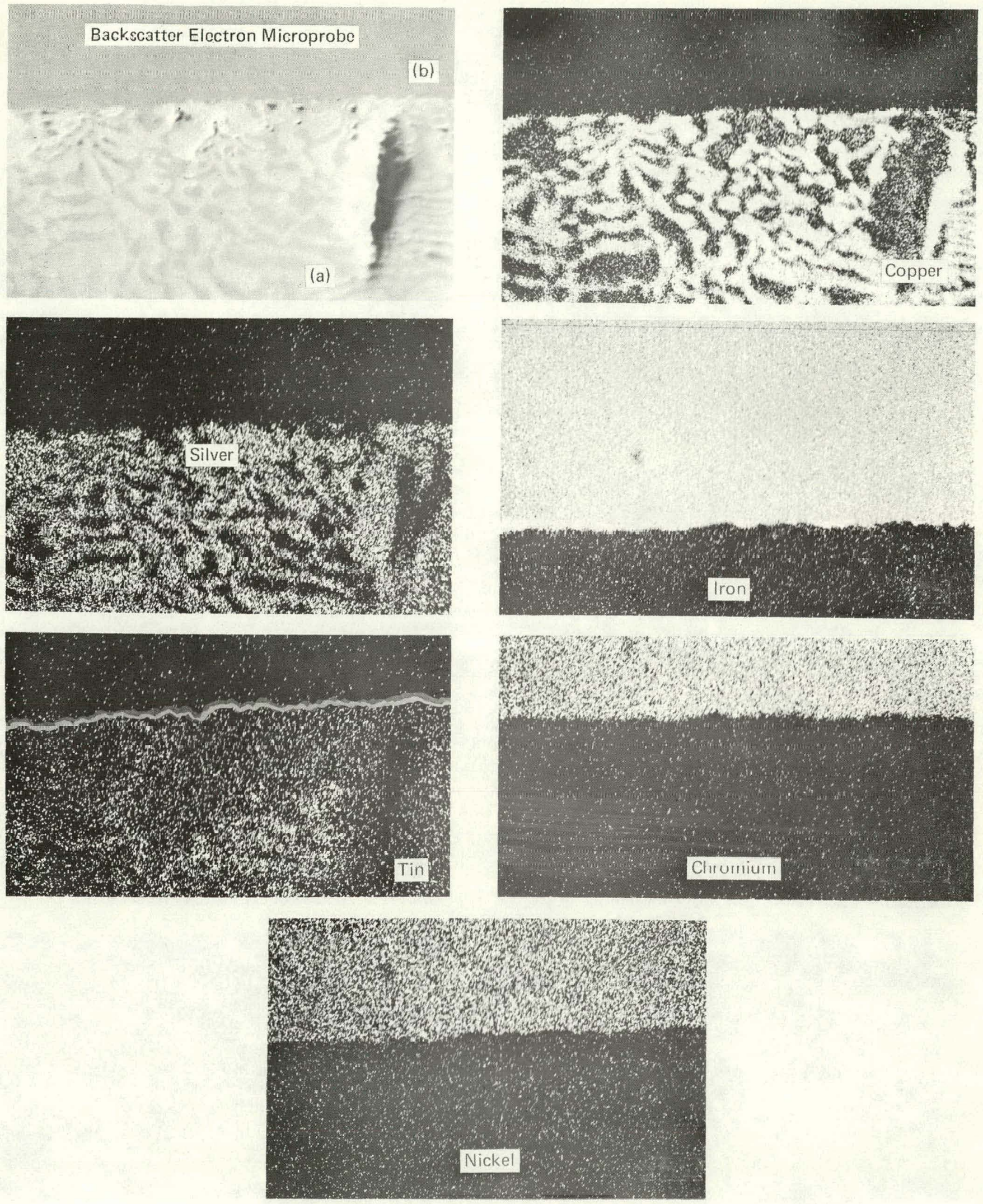

FIGURE 11. Cusiltin (a) (weight percents: 60 silver, 30 copper, and 10 tin) on Type-304L Stainless Steel (b) at $850{ }^{\circ} \mathrm{C}$. Magnification 88 percent of 500X. 

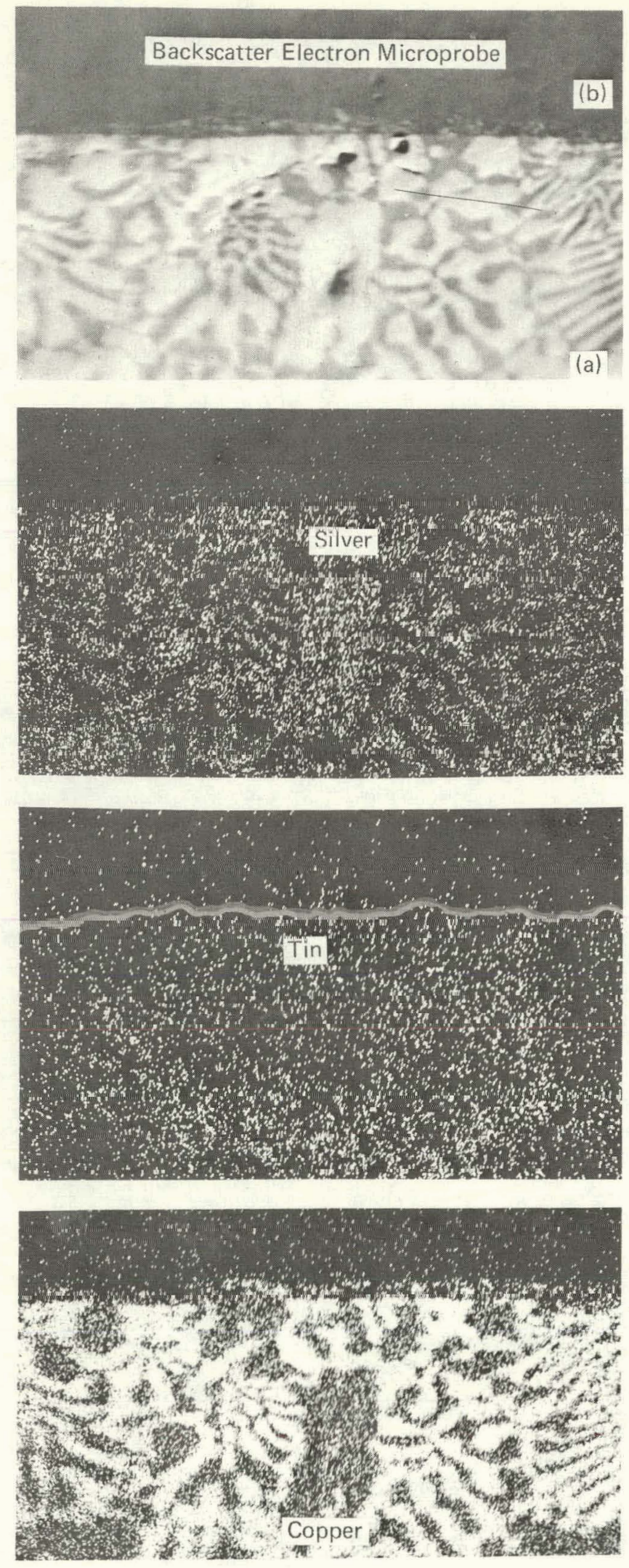
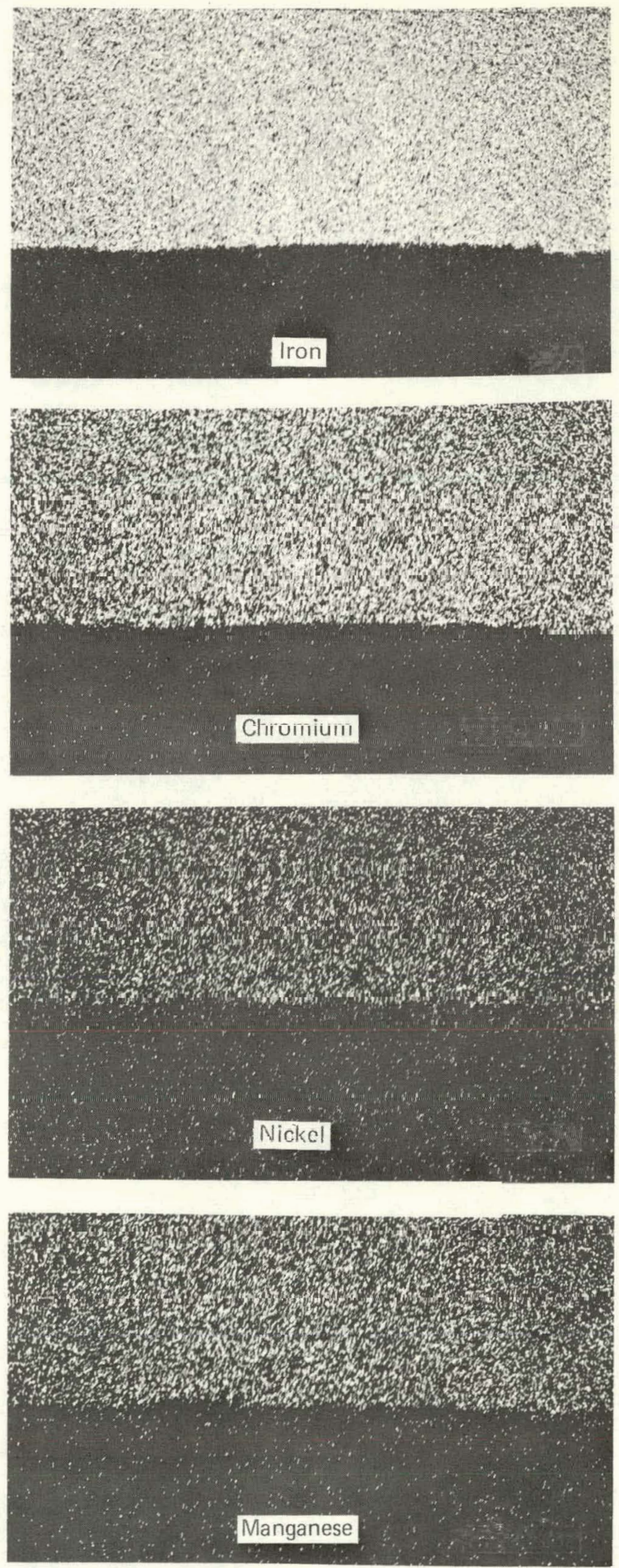

FIGURE 12. Cusiltin (a) (weight percents: 60 silver, 30 copper, and 10 tin) on Type 21-6-9 Stainless Steel (b) at $850^{\circ} \mathrm{C}$. Magnification 88 percent of 500X. 

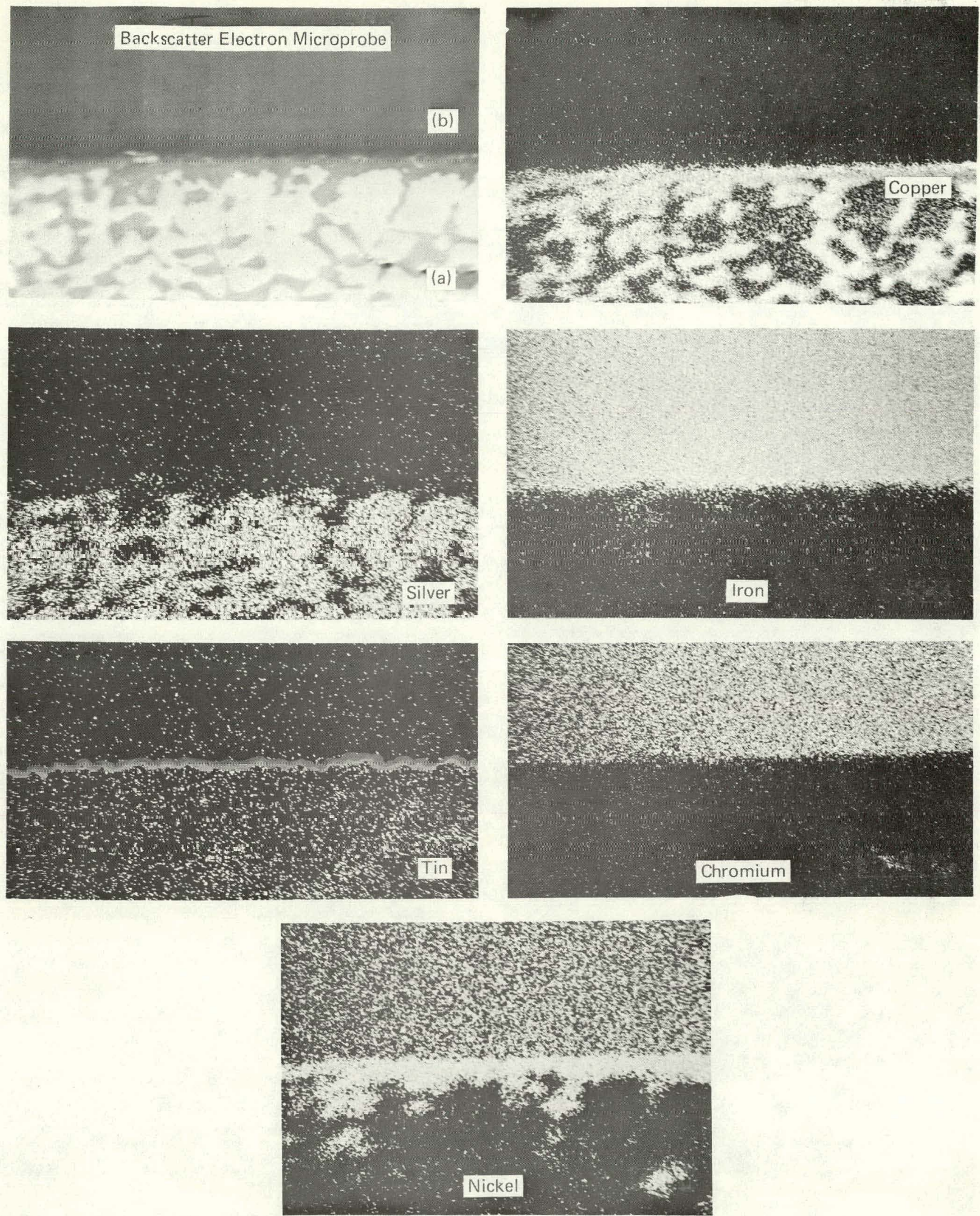

FIGURE 13. No. 630 (a) (weight percents: 63 silver, 28 copper, 6 tin, and 3 nickel) on Type-304L Stainless Steel (b) at $850^{\circ} \mathrm{C}$. Magnification 88 percent of $300 \mathrm{X}$. 

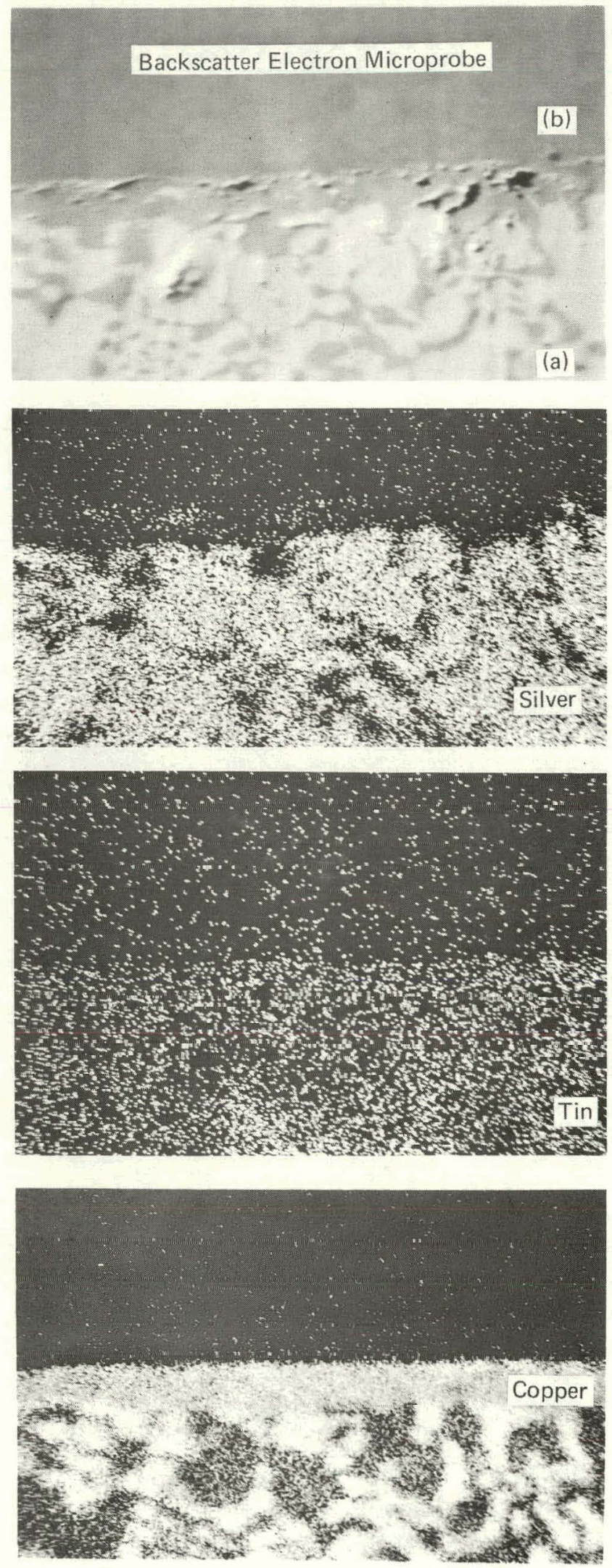
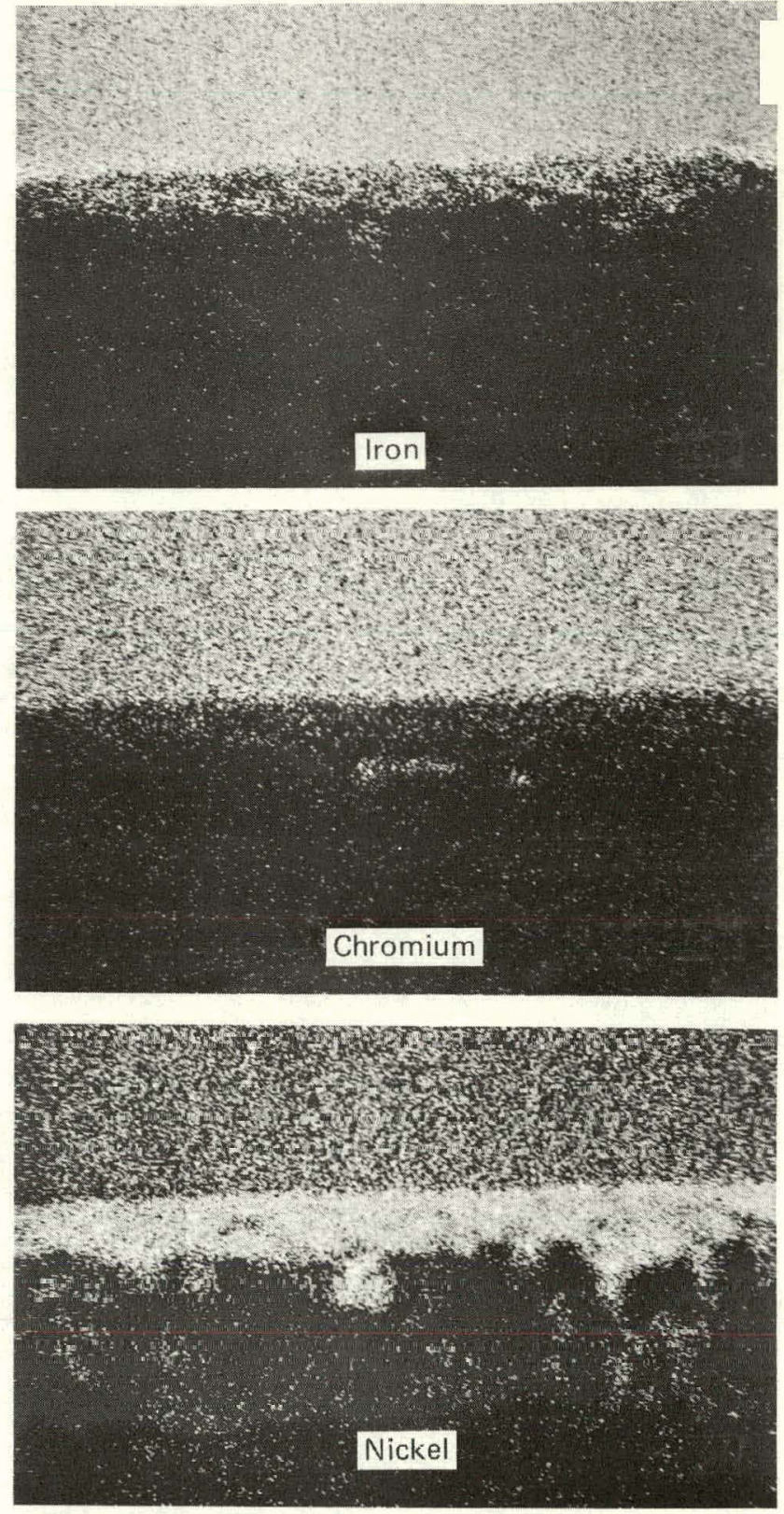

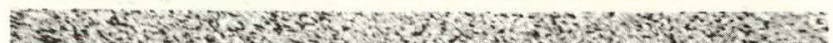

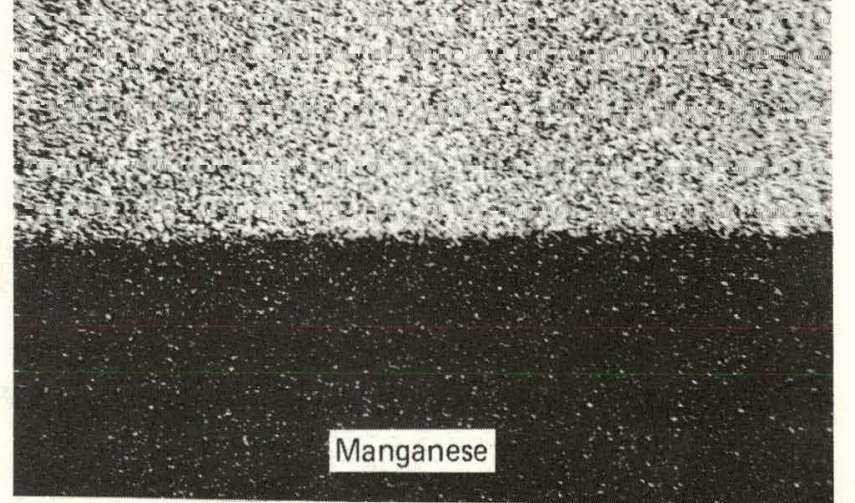

FIGURE 14. No. 630 (a) (weight perc.nts: 63 silver, 28 copper, 6 tin, and 3 nickel) on Type 21-6-9 Stainless Steel (b) at $850^{\circ} \mathrm{C}$. Magnification 88 percent of $500 \mathrm{X}$. 

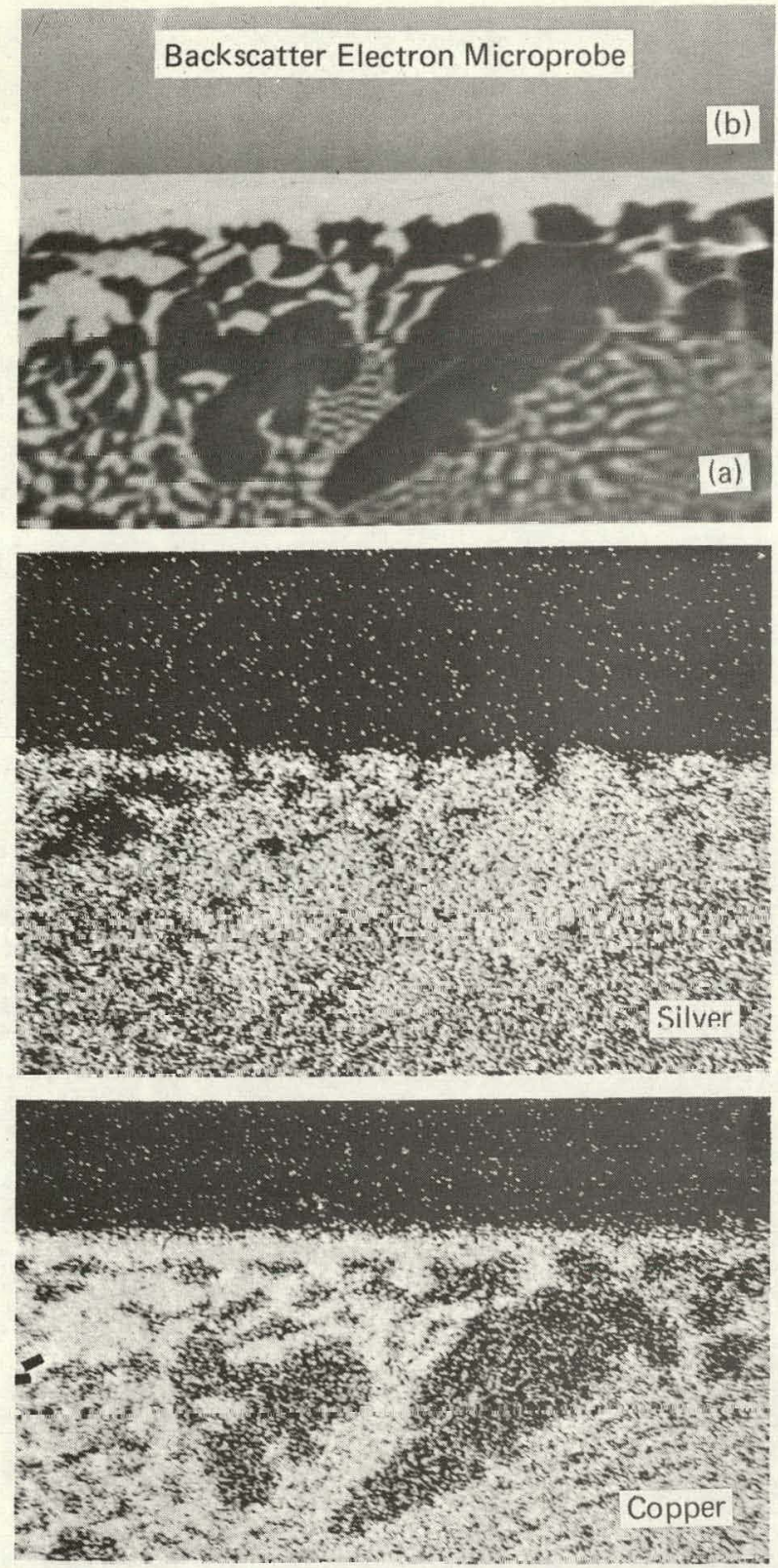
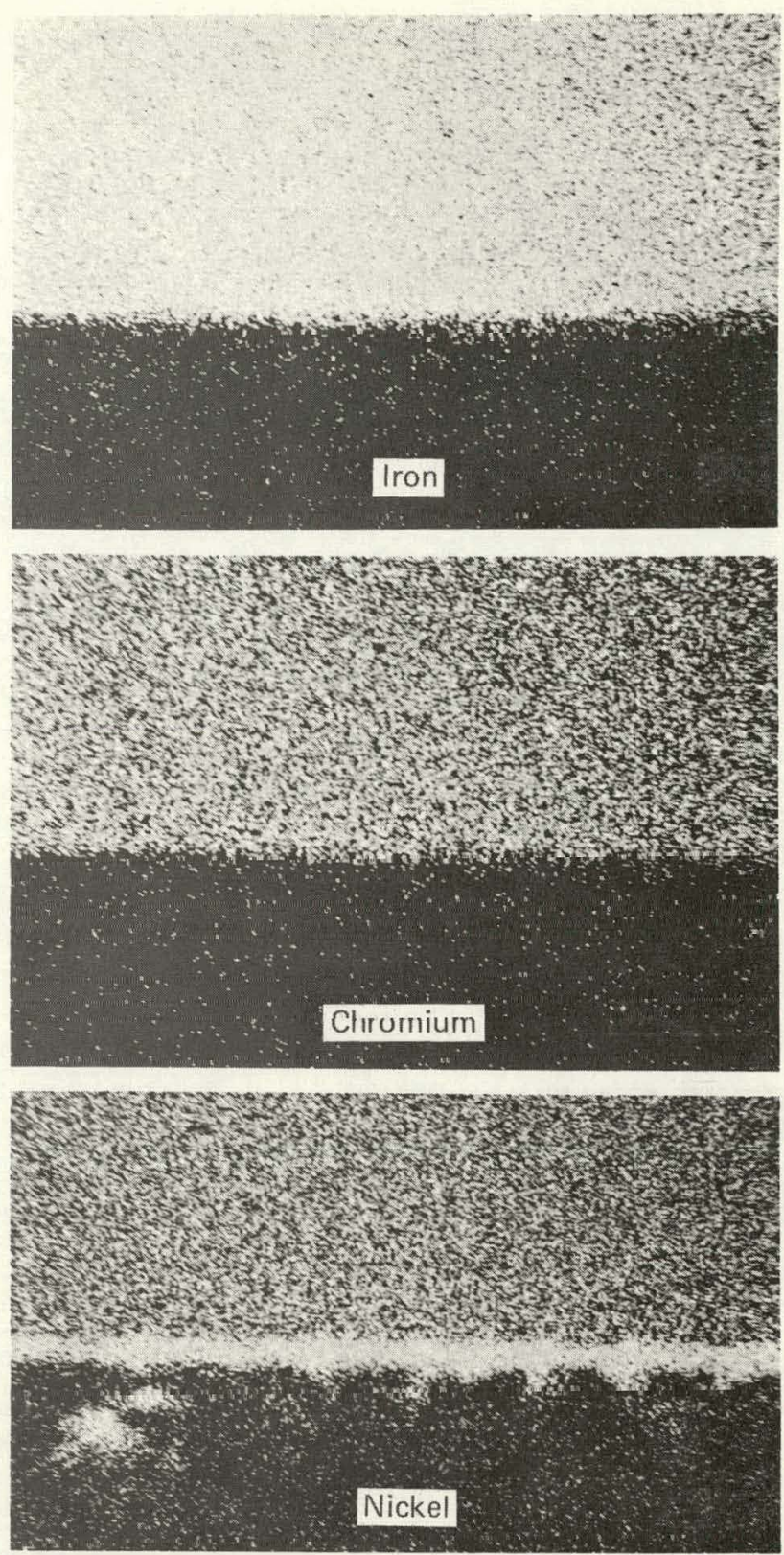

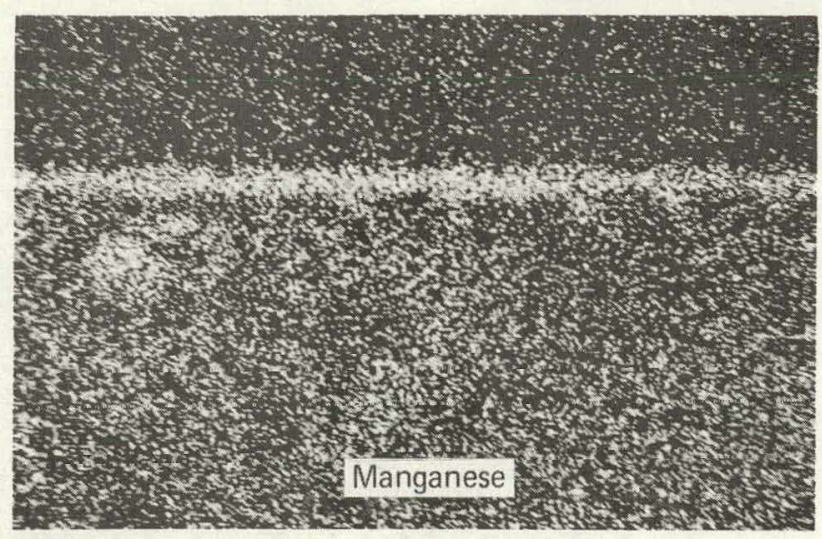

FIGURE 15. No. 655 (a) (weight percents: 65 silver, 28 copper, 5 manganese, and 2 nickel) on Type-304L Stainless Steel (b) at $900{ }^{\circ} \mathrm{C}$. Magnification 88 percent of 500X. 

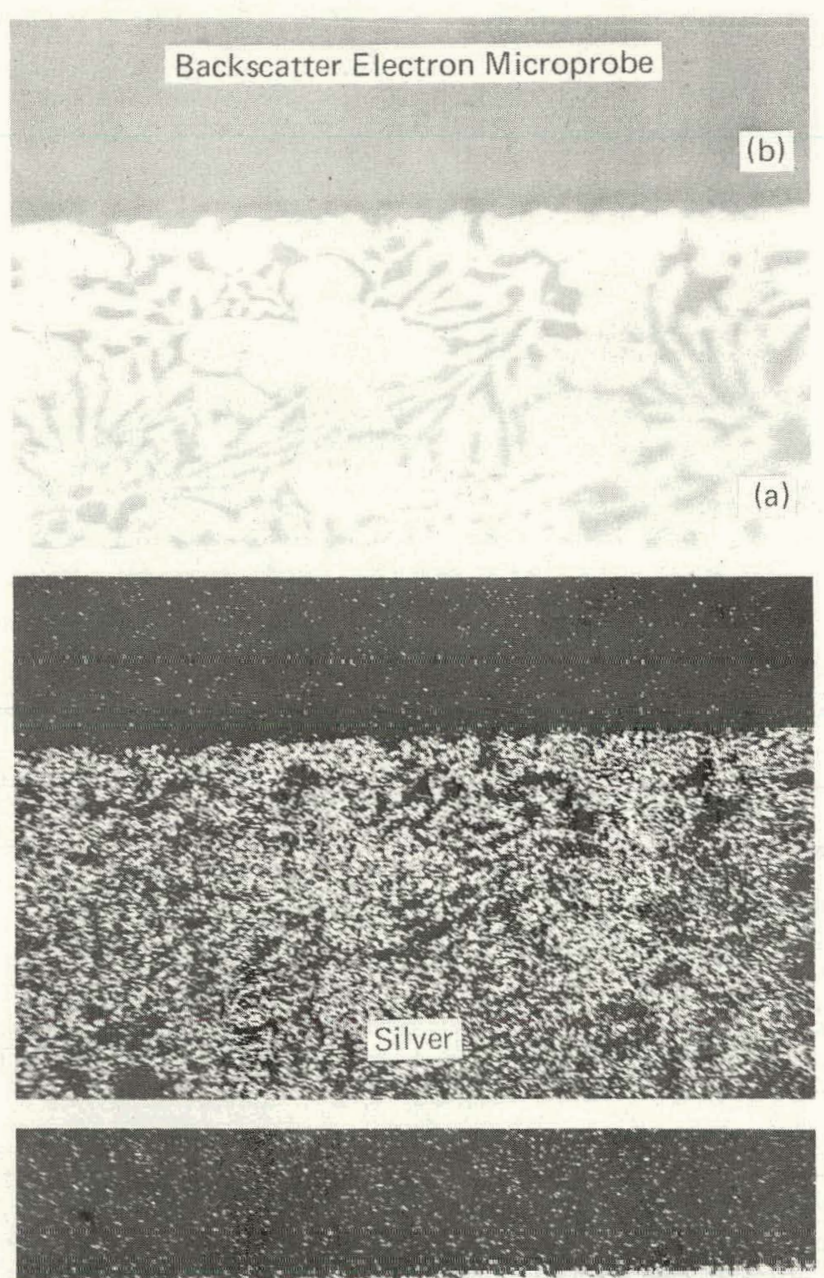

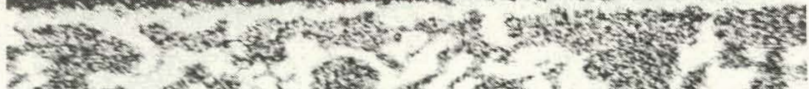

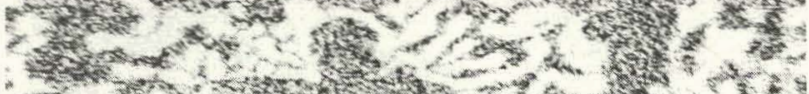

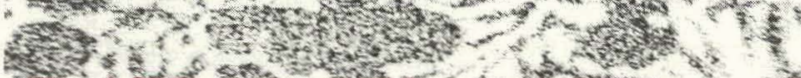
$-4 y^{2} y^{2}$.

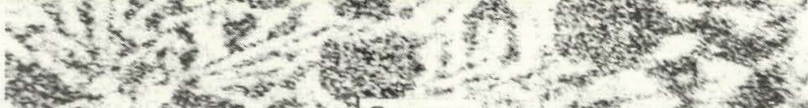
-2 $x^{2}$ s
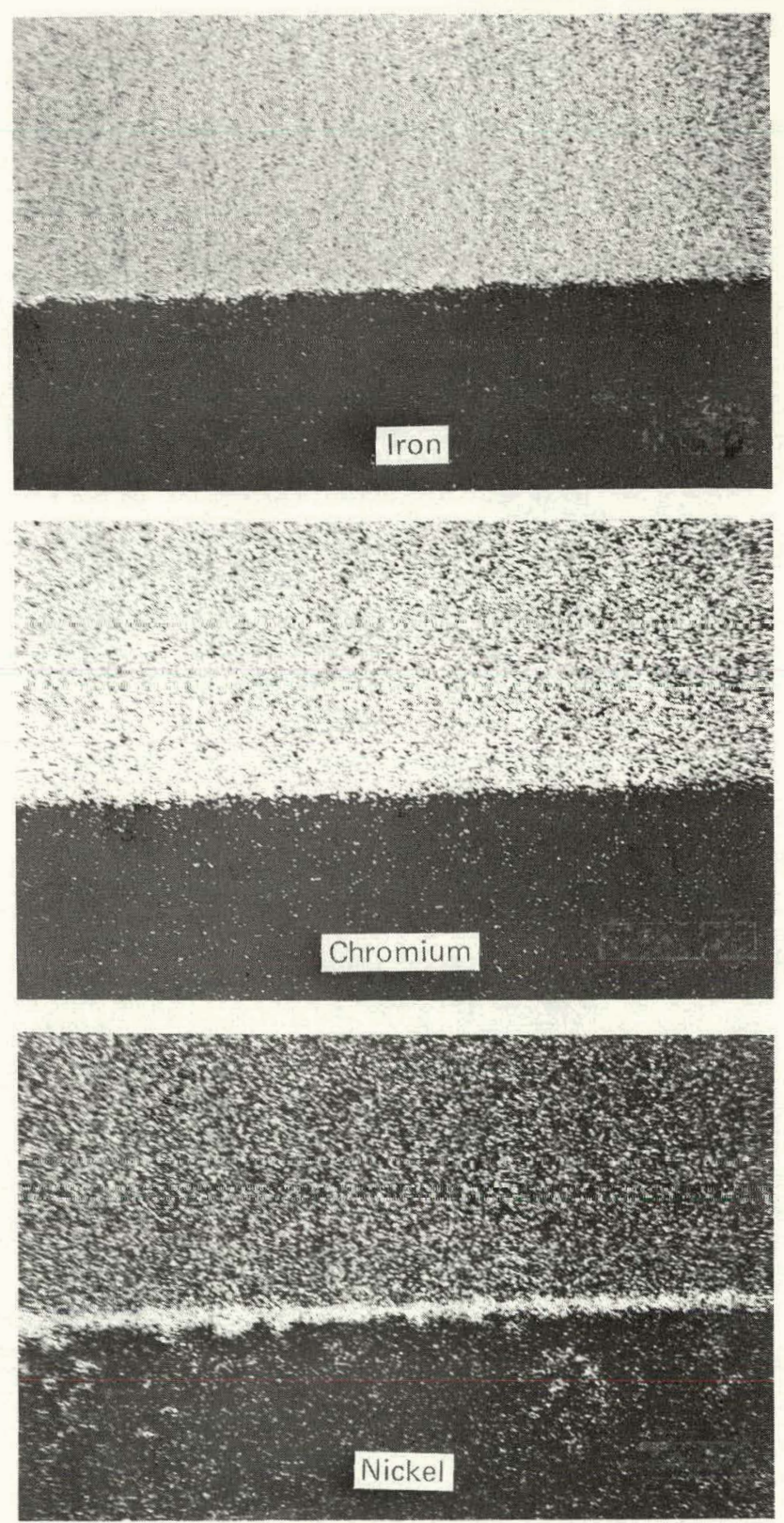

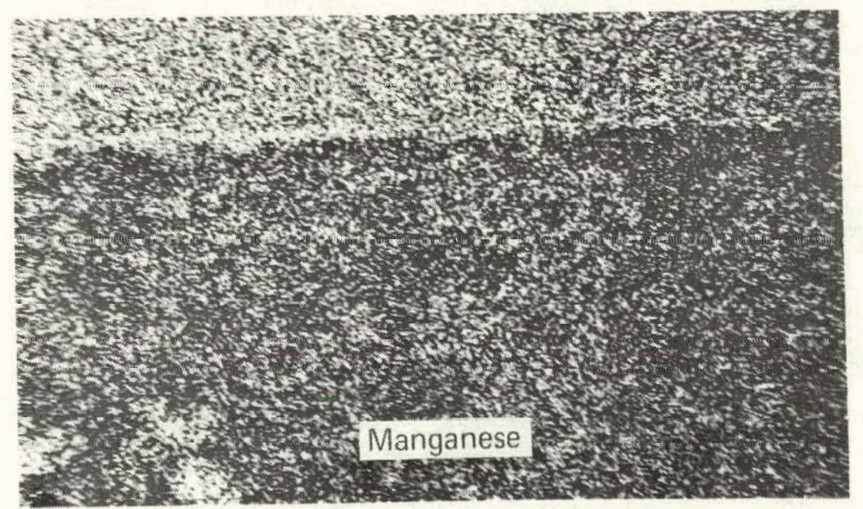

FIGURE 16. No. 655 (a) (weight percents: 65 silver, 28 copper, 5 manganese, and 2 nickel) on Type 21-6-9 Stainless Steel (b) at $900{ }^{\circ} \mathrm{C}$. Magnification 88 percent of 500X. 

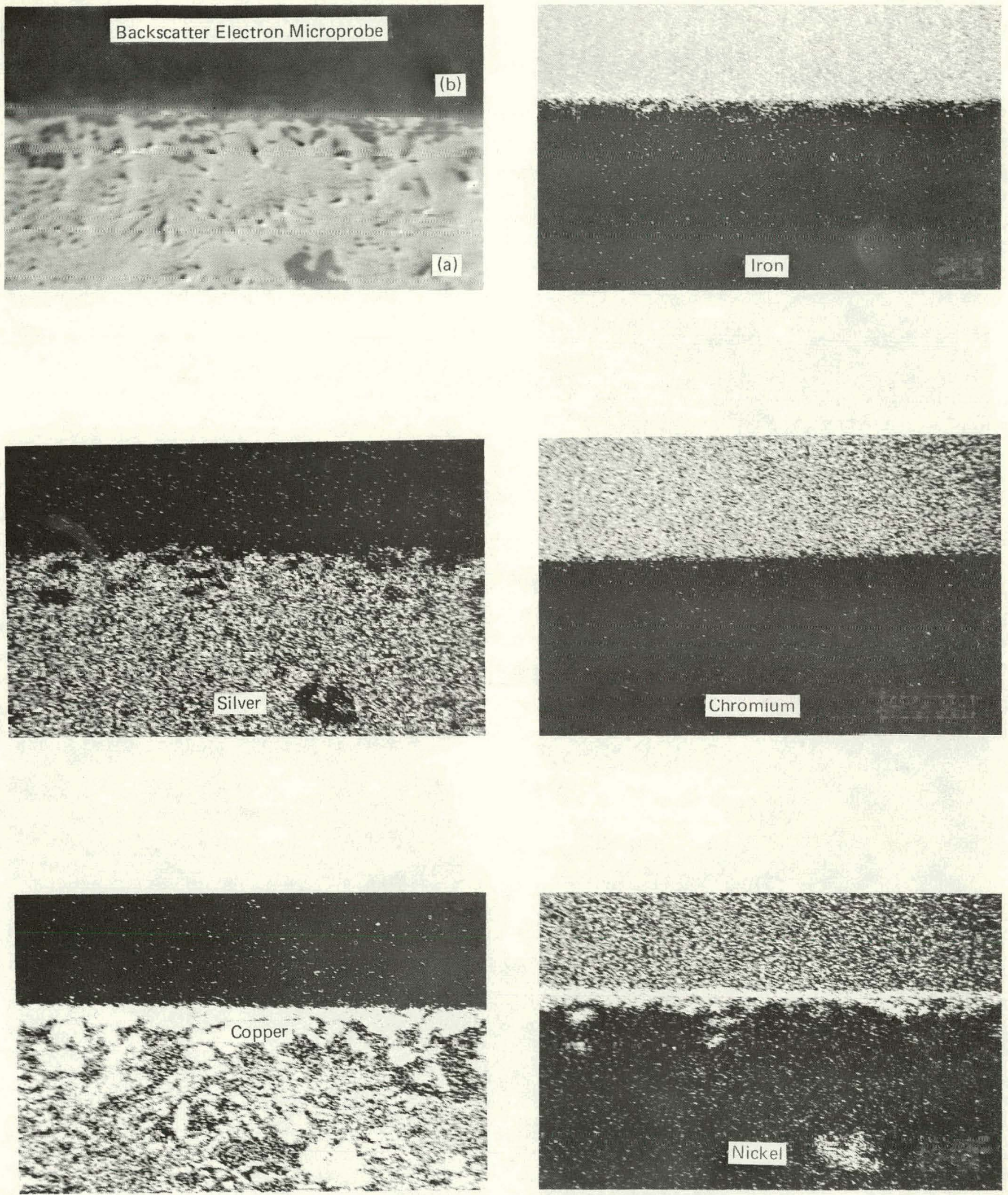

FIGURE 17. Nicusil (a) (weight percents: 71.5 silver, 28 copper, and 0.5 nickel) on Type-304L Stainless Steel (b) at $900{ }^{\circ} \mathrm{C}$. Magnification 88 percent of 500X. 

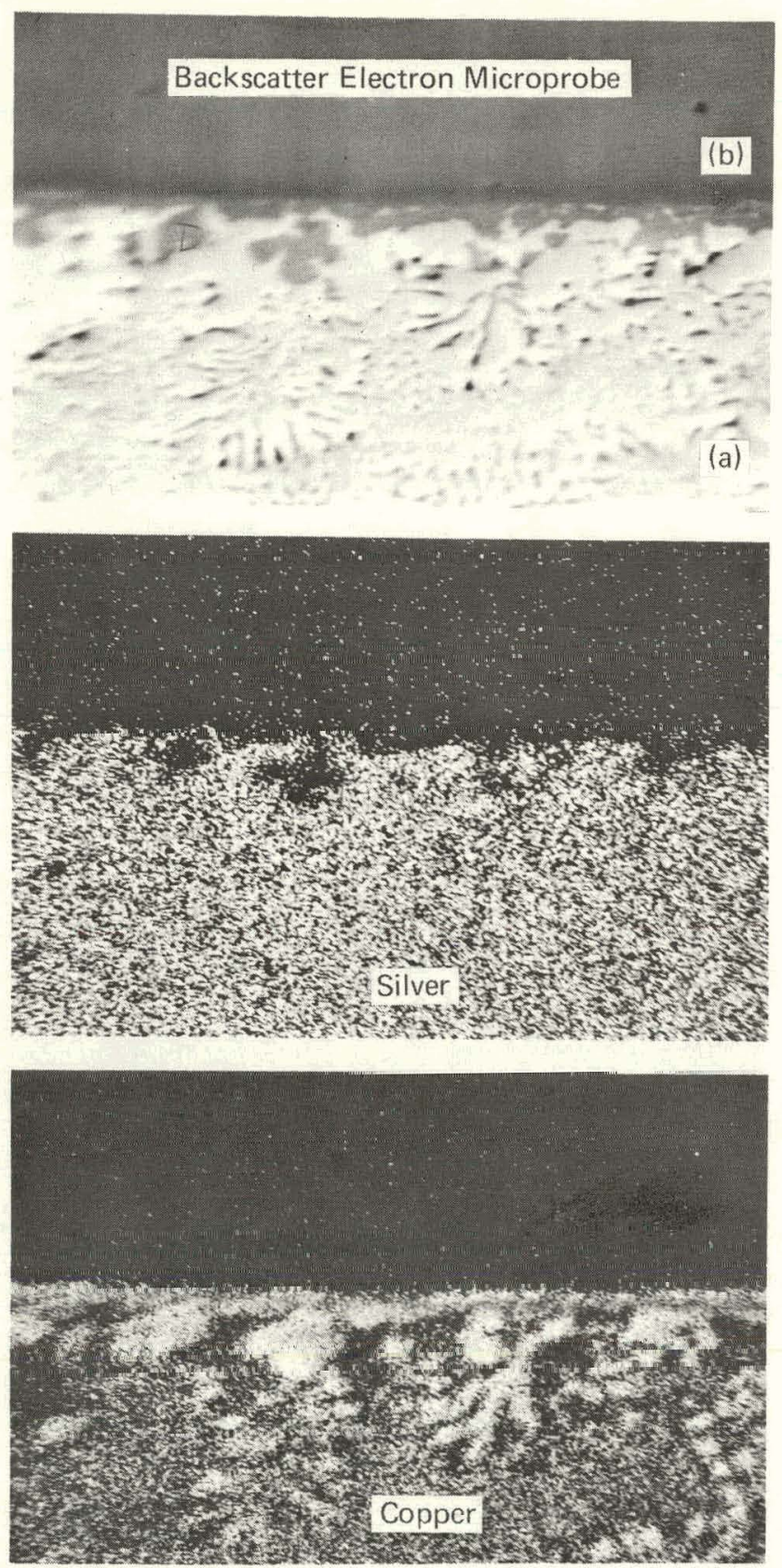
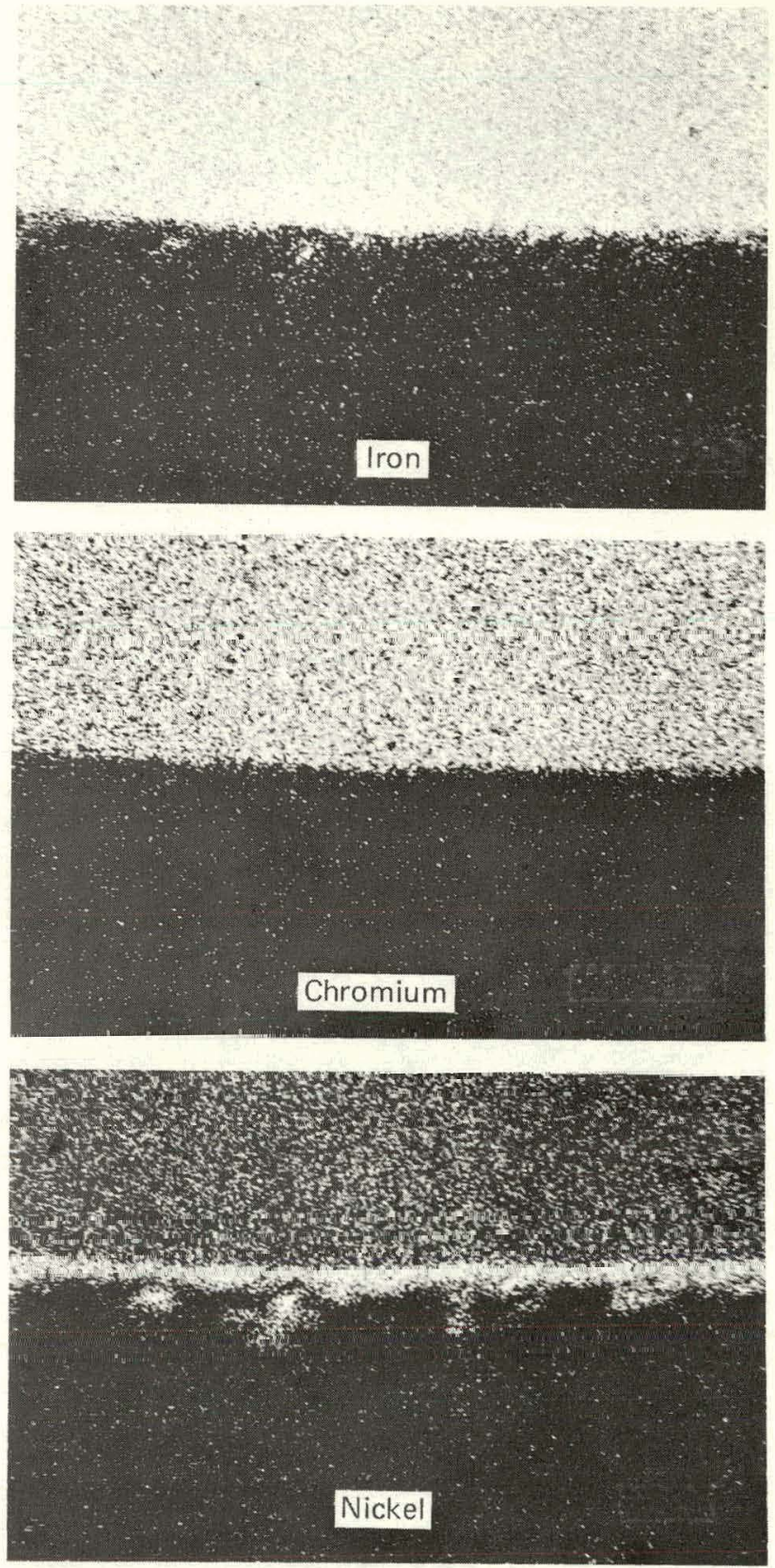

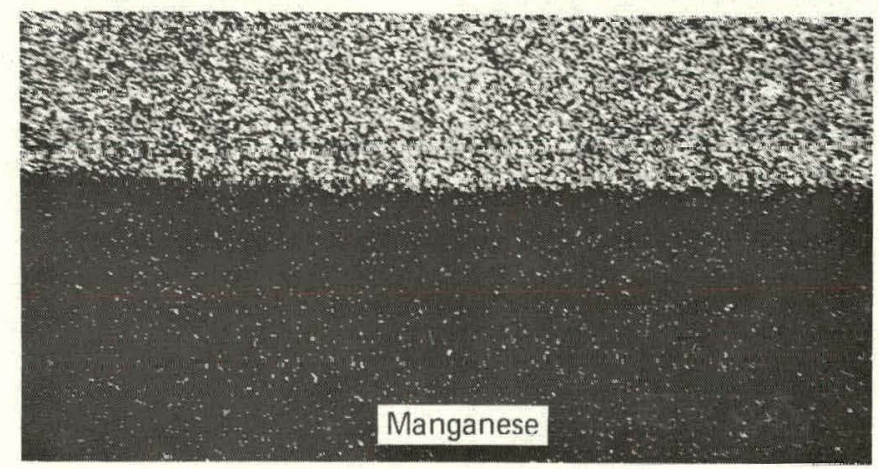

FIGURE 18. Nicusil (a) (weight percents: 71.5 silver, 28 copper, and 0.5 nickel) on Type 21-6-9 Stainless Steel (b) at $900{ }^{\circ} \mathrm{C}$. Magnification 88 percent of 500X. 

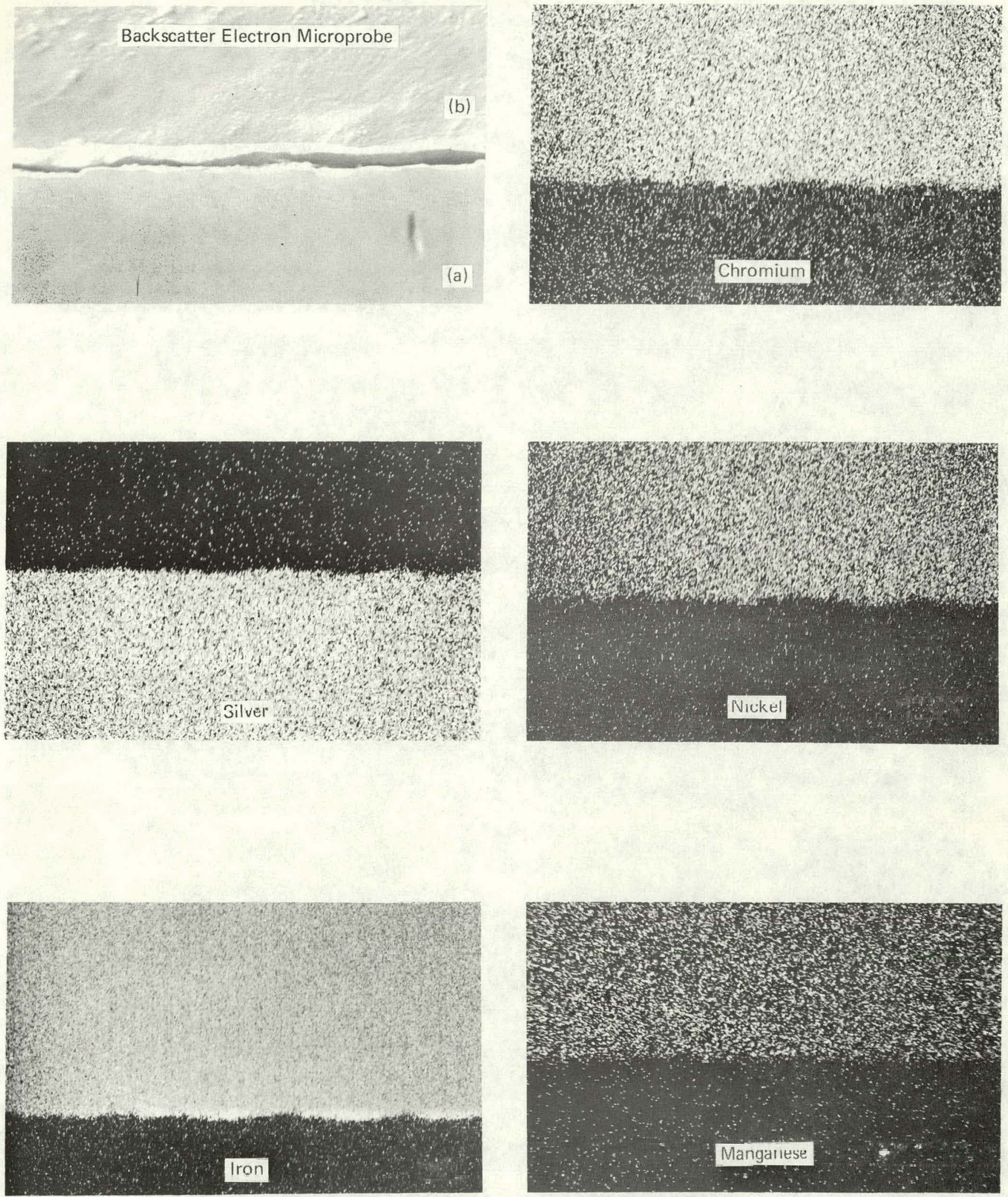

FIGURE 19. No. 852 (a) (weight percents: 85 silver and 15 manganese) on Type-304L Stainless Steel (b) at $1050{ }^{\circ} \mathrm{C}$. Magnification 88 percent of $500 \mathrm{X}$. 

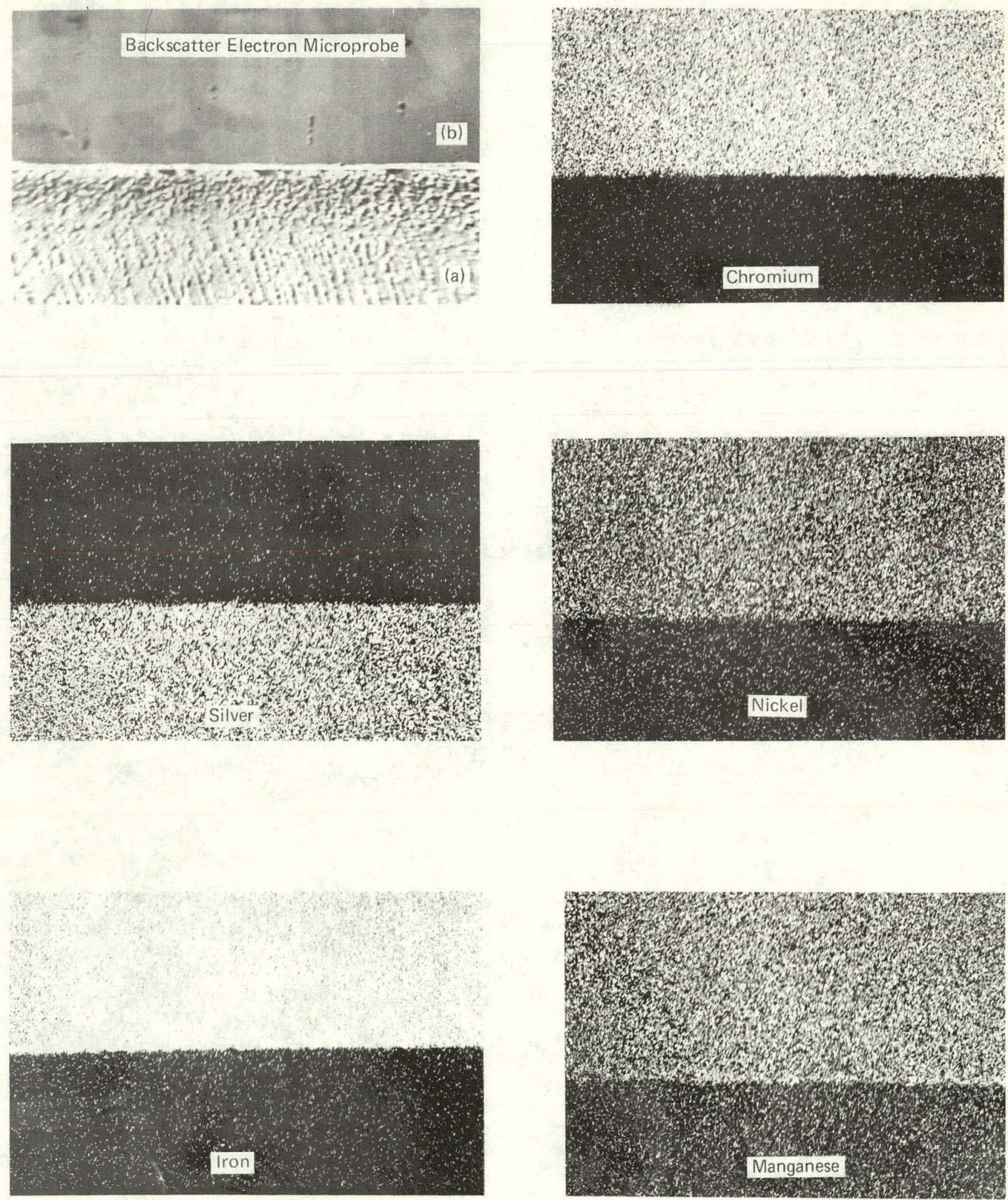

FIGURE 20. No. 852 (a) (weight percents: 85 silver and 15 manganese) on Type 21-6-9 Stainless Steel (b) at $1050{ }^{\circ} \mathrm{C}$. Magnification 88 percent of $500 \mathrm{X}$. 


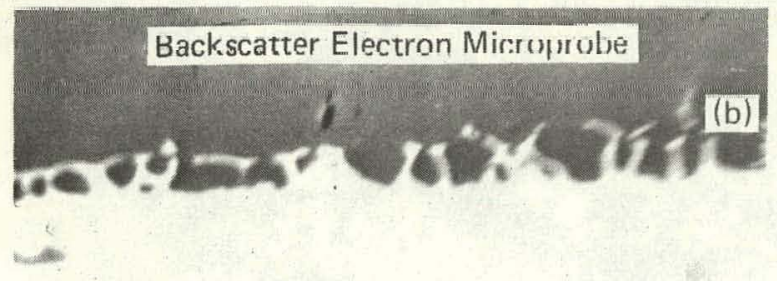

(a)
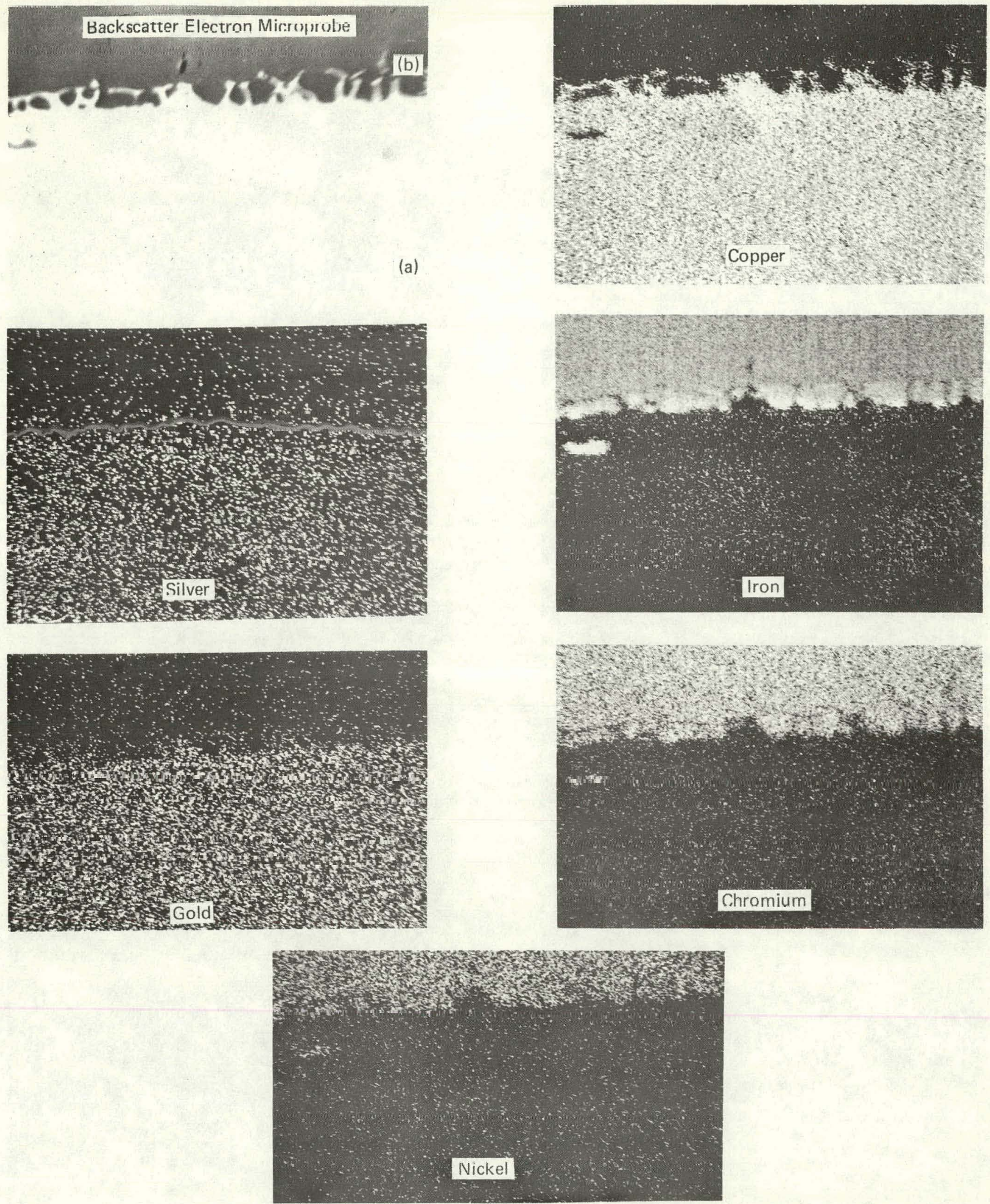

FIGURE 21. Silcoro 60 (a) (weight percents: 60 gold, 20 silver, and 20 copper) on Type-304L Stainless Steel (b) at $1000{ }^{\circ} \mathrm{C}$. Magnification 88 percent of $500 \mathrm{X}$. 

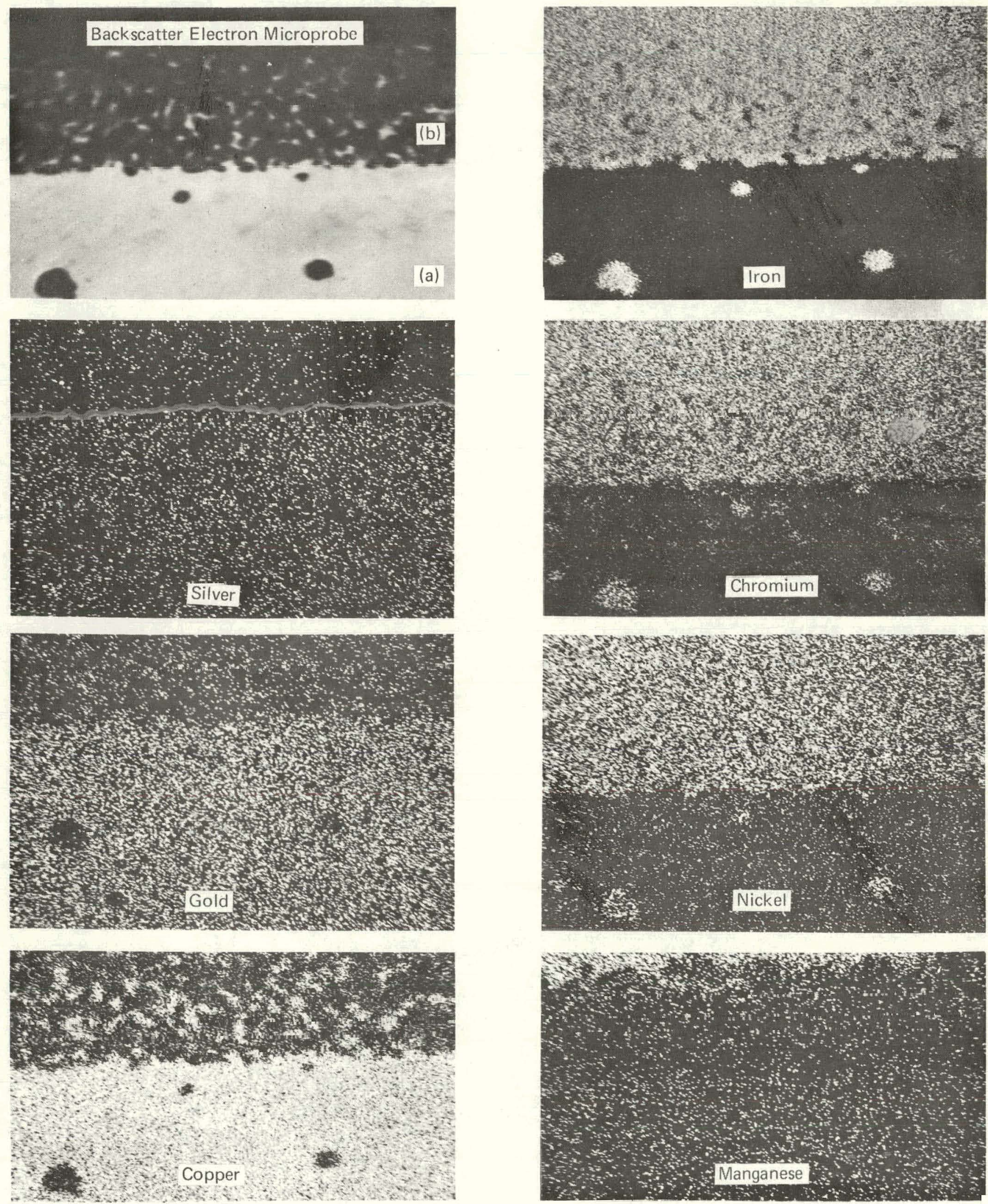

FIGURE 22. Silcoro 60 (a) (weight percents: 60 gold, 20 silver, and 20 copper) on Type 21-6-9 Stainless Steel (b) at $1000{ }^{\circ} \mathrm{C}$. Magnification 88 percent of 500X. 

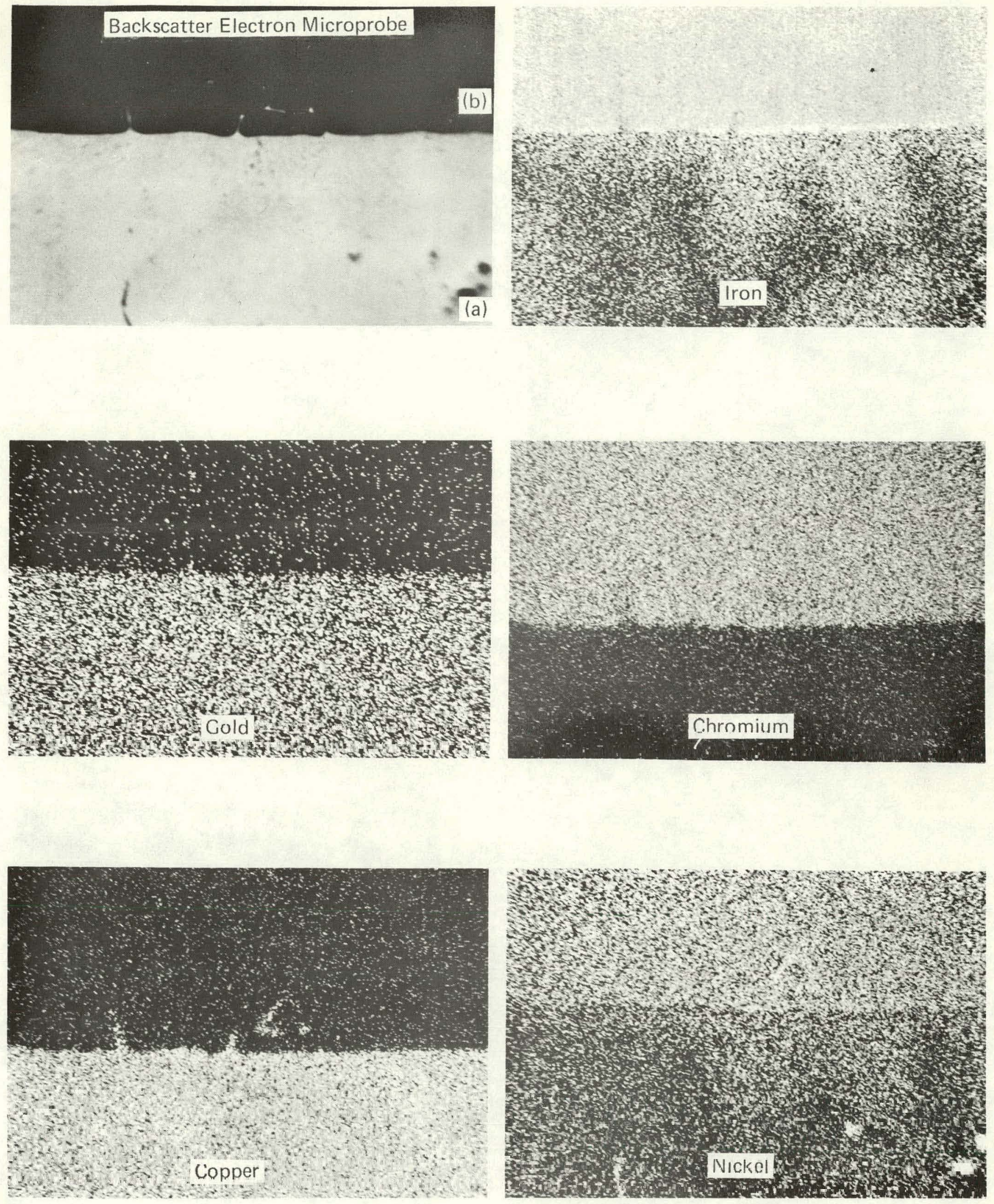

FIGURE 23. Nicoro 80 (a) (weight percents: 81.5 guld, 16 copper, and 2.5 nickel) on Type-304L Stainless Steel (b) at $1000{ }^{\circ} \mathrm{C}$. Magnification 500X. 

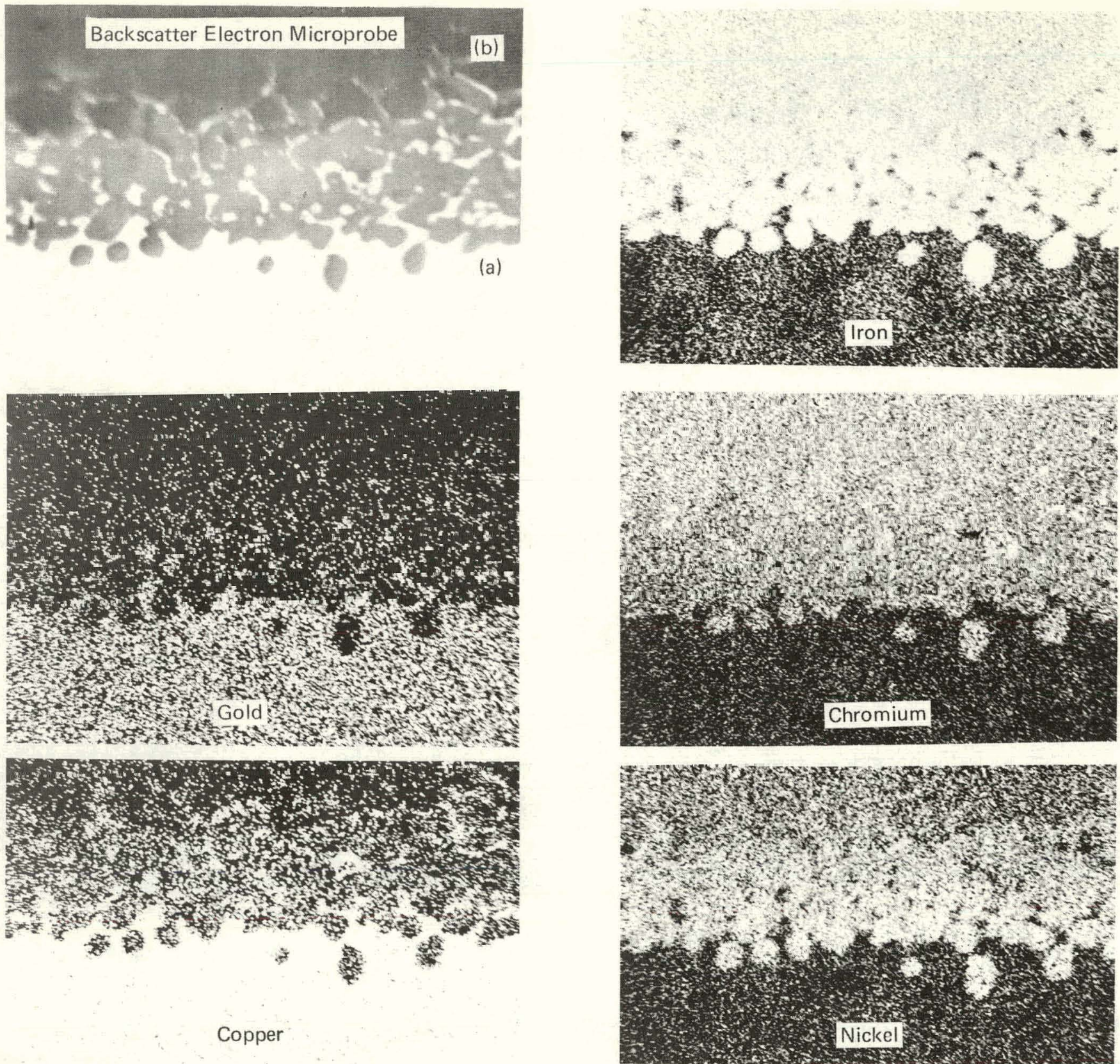

Copper

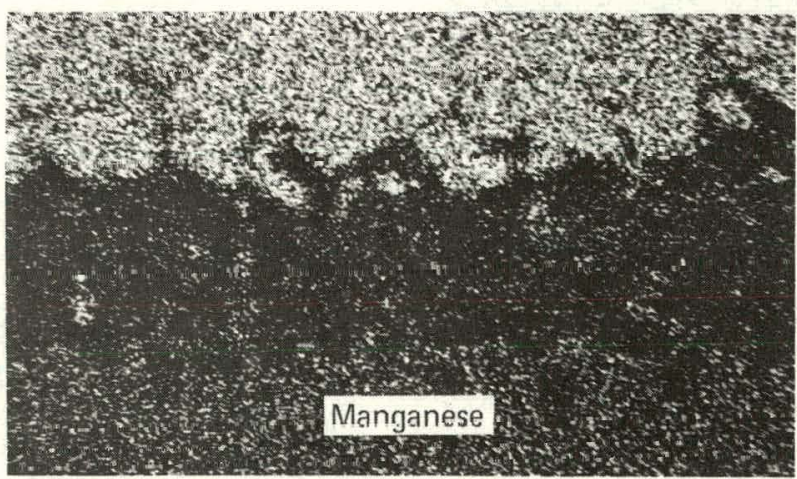

FIGURE 24. Nicoro 80 (a) (weight percents: 81.5 gold, 16 copper, and 2.5 nickel) on Type 21-6-9 Stainless Steel (a) at $1000^{\circ} \mathrm{C}$. Magnification 88 percent of 500X. 


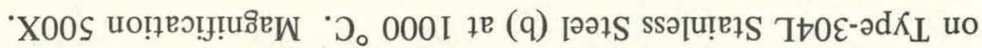

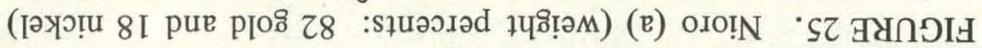
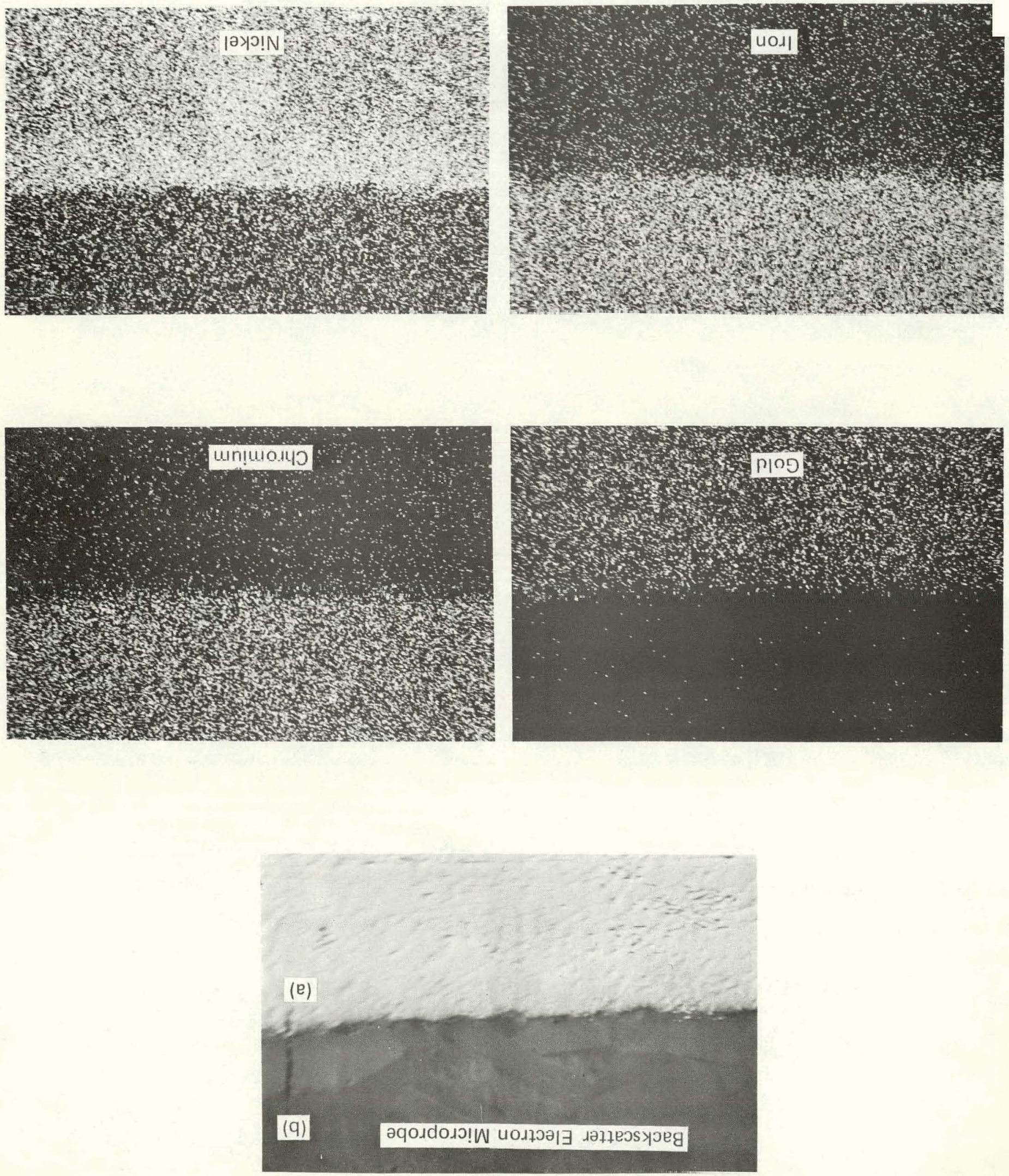

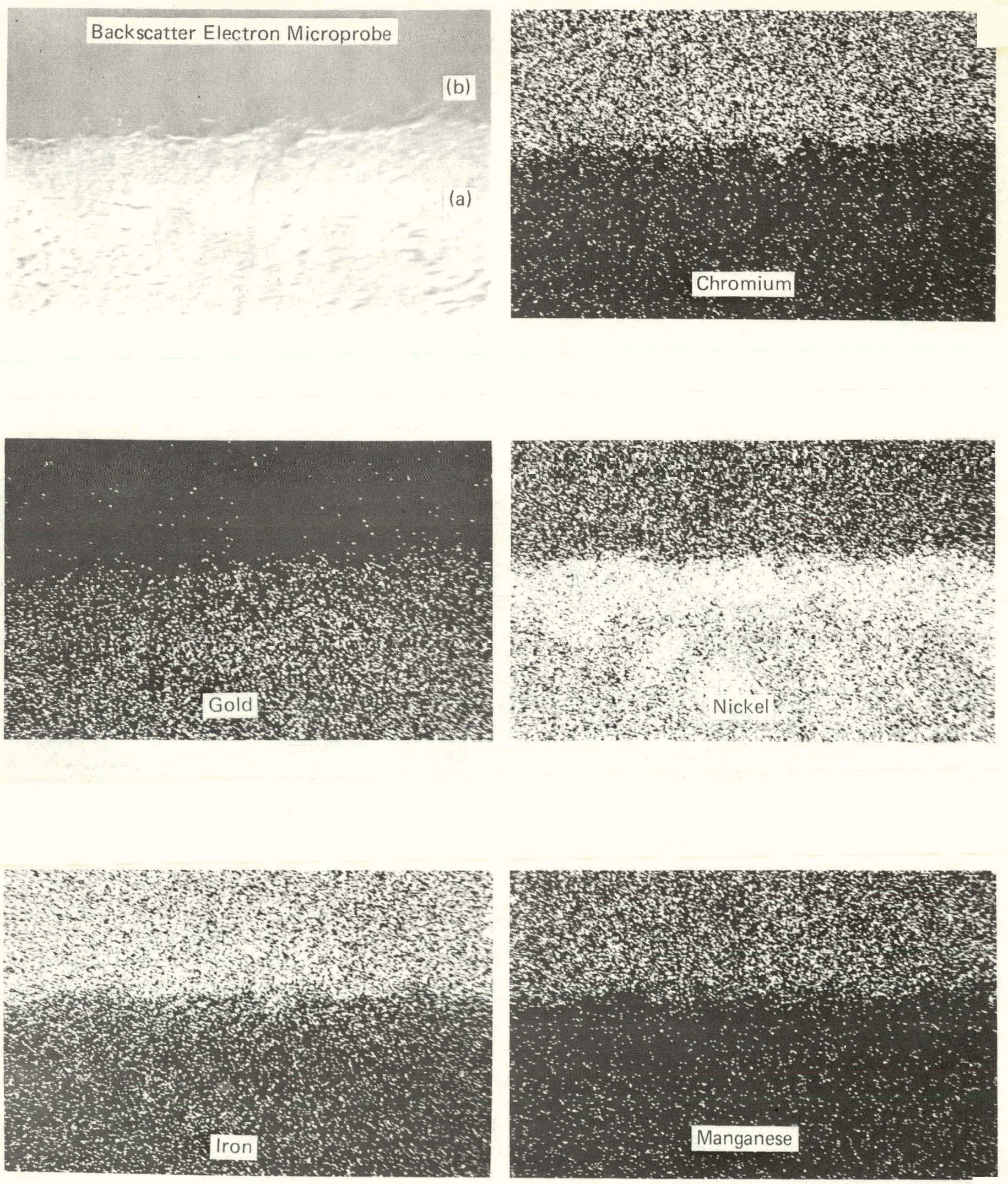

FIGURE 26. Nioro (a) (weight percents: 82 gold and 18 nickel) on Type 21-6-9 Stainless Steel (b) at $1000^{\circ} \mathrm{C}$. Magnification 500X. 